\title{
CEOs' Prosocial Behavior, Their Careers and Corporate Policies
}

\author{
Mei Feng \\ Katz Graduate School of Business \\ University of Pittsburgh \\ Pittsburgh, PA 15260 \\ mfeng@katz.pitt.edu
}

\author{
Weili Ge* \\ Michael G. Foster School of Business \\ University of Washington \\ Seattle, WA 98195 \\ geweili@uw.edu \\ Zhejia Ling \\ College of Business and Economics \\ California State University, Fullerton \\ Fullerton, CA 92834 \\ zling@fullerton.edu \\ Wei Ting Loh \\ Singapore Management University \\ Michael G. Foster School of Business \\ University of Washington \\ Seattle, WA 98195 \\ weiloh@uw.edu
}

September 1, 2020

We would like to thank Shane Johnson, Dawn Matsumoto, Sarah McVay, Donald Moser, Shawn Thomas, and Xing Su, as well as seminar participants at the University of Washington, the University of Pittsburgh, and Syracuse University for their valuable comments and suggestions. Any errors or omissions are our responsibility.

* Corresponding author. 


\title{
CEOs' Prosocial Behavior, Their Careers and Corporate Policies
}

\begin{abstract}
This paper examines the associations of Chief Executive Officers' (CEOs') prosocial behavior with their career paths and corporate policies. Using individuals' involvement with charitable organizations as a proxy for prosocial behavior, we find that prosocial individuals are promoted to CEOs faster than non-prosocial individuals. In addition, compared with firms with non-prosocial CEOs, firms with prosocial CEOs tend to have lower executive subordinate turnover, implement more employee-friendly policies, experience higher customer satisfaction, and engage in more socially responsible activities. We also find that firms with prosocial CEOs have higher firm value. These results are corroborated when we compare changes in corporate policies and firm value around different types of CEO turnovers: a prosocial CEO replacing a non-prosocial CEO versus other types of CEO turnovers. Our results thus suggest that prosocial CEOs are more likely to make corporate decisions that benefit a wide range of firm stakeholders.

Keywords: Prosocial behavior; CEO Career; Corporate policies; Employee turnover; Customer satisfaction; Corporate social responsibility.
\end{abstract}

JEL Classification: D64, G40, G41, J24, M14, M51

Data Availability: All data are publicly available or available from the subscription sources identified in the text. 


\section{CEOs' Prosocial Behavior, Their Careers and Corporate Policies}

\section{Introduction}

Individuals often engage in prosocial behavior - activities that primarily benefit others. For example, people make financial or nonfinancial donations (e.g., giving blood), volunteer at charitable organizations, and help strangers (Batson and Powell, 2003). ${ }^{1}$ While individuals usually engage in such behavior to increase others' well-being, prior studies have documented that prosocial behavior also significantly improves the provider's own psychological well-being, such as through increased levels of happiness and life satisfaction. ${ }^{2}$ Moreover, prosocial behavior, particularly volunteering, can help providers to develop their social network and job-related skillsets (e.g., Harlow and Cantor, 1996; Meier and Stutzer, 2008; Wilson, 2012).

To the extent that prosocial behavior reveals individuals' other-regarding preferences and equips them with better skillsets and social connections, individuals who engage in prosocial behavior (hereafter prosocial individuals) are likely to have different career paths and make different decisions in their jobs. This paper investigates these issues by focusing on prosocial Chief Executive Officers (CEOs). Specifically, we ask two questions. First, does the time taken to reach the CEO position differ between prosocial and non-prosocial individuals? Second, once a prosocial individual becomes a CEO, does she treat the firm's stakeholders, including its employees, customers, shareholders, and the society differently from a non-prosocial CEO?

It is unclear, ex ante, how prosocial tendencies affect a manager's career development. On the one hand, prosocial behavior leads to better emotional well-being and job skills (Sieber, 1974;

\footnotetext{
${ }^{1}$ For example, based on a survey by Americorps in 2018, 30.3\% of American adults volunteer through an organization. According to Giving USA, individuals donated $\$ 281.86$ billion to charity in 2016, which represents $72 \%$ of all charitable donations in that year (https://giving usa.org/tag/giving-usa-2017/).

${ }^{2}$ Other non-mutually exclusive incentives behind prosocial behavior are to establish a social reputation of being a "good" person and to obtain financial rewards (Benedou and Tirole, 2006; Carpenter and Myers, 2010). Please see more detailed discussion in Section 2.
} 
Marks, 1977; Anik, Aknin, Norton, and Dunn, 2009), which can increase an individual's productivity at work. In addition, a prosocial manager may benefit from increased trust among her coworkers as well as an improved social reputation and network, and thus be more effective in her job (Whitener, Brodt, Korsgaard, and Werner, 1998). On the other hand, prosocial behavior also consumes a manager's resources such as time and effort, which could compromise her job performance, and thus negatively affect her career advancement to a top management position.

We measure prosocial behavior for a broad cross-section of individuals using their involvement with charitable organizations, since the primary objective of such organizations is to improve societal welfare by helping people in need. Specifically, we use the BoardEx database to obtain data on managers' off-the-job activities, including involvement with various foundations and charitable groups. We define an individual as prosocial if she is involved with at least one organization that is classified as a charitable organization by the Internal Revenue Service (IRS). ${ }^{3,4}$

We find that it takes a prosocial individual significantly less time to be promoted to CEO than a non-prosocial individual, after controlling for factors that may affect manager promotion such as educational background and experience in non-charitable organizations. On average, relative to non-prosocial individuals, prosocial individuals are promoted to the CEO position 1.398 years faster. Since it takes about 22 years for an individual to be promoted to a CEO position from the start of her career on average, this magnitude is economically meaningful.

We next examine whether a prosocial individual, after becoming a CEO, makes different

\footnotetext{
${ }^{3}$ The IRS defines "charitable" as follows: "The term charitable is used in its generally accepted legal sense and includes relief of the poor, the distressed, or the underprivileged; eliminating prejudice and discrimination; defending human and civil rights secured by law; and combating community deterioration and juvenile delinquency." (https://www.irs.gov/charities-non-profits/charitable-purposes).

4 The most popular position CEOs hold in charitable organizations is board member. According to IRS's Governance and Related Topics - 501(c)(3) Organizations (2008), charities should generally not compensate persons for service on the board of directors except to reimburse direct expenses of such service. Therefore, it is reasonable to assume that being a board member of charitable organization is prosocial behavior.
} 
corporate decisions regarding various firm stakeholders than a non-prosocial CEO. To the extent that a prosocial CEO is more concerned about others' well-being, she is likely to build a more trusting relationship with her employees, care more about her customers' satisfaction, and engage in more corporate social responsibility (CSR) activities than a non-prosocial CEO. To test these predictions, we conduct two sets of analyses. In the first set of analyses, we use all observations for which we can obtain data on CEO prosocial behavior and other necessary variables. This sample constitutes our full sample. It is possible, however, that the associations between having a prosocial CEO and certain corporate policies in our full sample are driven by underlying firm characteristics, such as firm culture or tradition. To address this concern, in the second set of tests, we focus on firms with CEO turnovers during our sample period and examine corporate policy changes around CEO turnovers. This sample allows us to examine whether a change in CEO prosocial type (i.e., a switch between prosocial and non-prosocial CEOs) leads to changes in corporate policies.

To investigate how prosocial CEOs treat employees, we first test whether the turnover of executive subordinates is lower for firms with prosocial CEOs than for firms with non-prosocial CEOs. We focus on executive subordinates such as Chief Financial Officers (CFOs) and Chief Operating Officers (COOs), since they work and interact closely with CEOs. Thus, a CEO's prosocial tendency and her relationship with executive subordinates are likely to influence their turnover rate. We find that for executive subordinates below the age of 50, having a prosocial CEO reduces their likelihood of leaving the firm in the following year by $1.3 \%$, after controlling for firm performance, subordinate characteristics, etc. ${ }^{5}$ This result is statistically significant and also economically meaningful, given that the average executive subordinate turnover rate in our sample

\footnotetext{
${ }^{5}$ We focus on subordinates below the age of 50 because older subordinates have less career mobility, and therefore are less likely to leave their firm for reasons related to their relationships with CEOs. Please see more supporting evidence and discussion in Section 4.2.1.
} 
is $17.5 \%$. In contrast, we find that a CEO's involvement with non-charitable organizations is not significantly associated with executive subordinate turnover, suggesting that the negative association between CEOs' prosocial behavior and subordinate turnover is not driven by CEOs' involvement in general off-the-job activities, but by CEOs' prosocial tendency.

We also examine how prosocial CEOs treat their rank-and-file employees by looking at their firm's policies related to employee welfare such as the firm's union relations, cash profitsharing plans, worker involvement, retirement benefits, and policies on employee health and safety. We obtain firms' employee relations rating from the KLD STATS database and find that a firm's rating on employee welfare is significantly and positively associated with CEO involvement in charitable organizations, but not with CEO involvement in non-charitable organizations. This result suggests that firms with prosocial CEOs are more likely to have corporate policies that consider their employees' welfare.

We then turn to another important group of stakeholders of the firm: customers. We investigate whether prosocial CEOs care more about customers by examining the level of their customers' satisfaction, measured by customer satisfaction scores from the American Customer Satisfaction Index (ACSI). We find that customer satisfaction is significantly and positively associated with CEO involvement in charitable organizations, but not with CEO involvement in non-charitable organizations. This result indicates that firms with prosocial CEOs are more customer-centric than those with non-prosocial CEOs.

We also examine whether prosocial CEOs are more likely to consider overall societal welfare in their decision making, using the KLD STATS rating of firm policies on various CSR initiatives such as community, employee relations and environment. We find that firms' overall CSR rating is significantly and positively associated with CEO prosocial behavior, suggesting that firms with prosocial CEOs have more socially responsible policies. 
Finally, we investigate the association between CEO prosocial tendency and firm value and performance, measured by Tobin's Q, size-adjusted stock returns and return on total assets (ROA). We find that prosocial CEOs are associated with higher Tobin's Q, stock returns and ROA.

We continue to find consistent results in the second set of analyses, where we compare corporate policy changes around different types of CEO turnovers. Specifically, we find that after a prosocial CEO replaces a non-prosocial CEO, firms experience less increases in subordinate turnover and less decreases in employee-friendly policies, customer satisfaction and overall CSR activities than after other types of CEO replacements. Overall, these results suggest that prosocial CEOs improve subordinate retention, establish more employee-friendly policies, have higher customer satisfaction, and engage in more socially responsible activities. We also find that Tobin's Q increases more after a prosocial CEO replaces a non-prosocial CEO than other types of CEO turnovers. However, changes in size-adjusted stock returns and ROA are not significantly associated with the type of CEO turnover.

One caveat of our paper is that our proxy for CEO prosocial tendency (i.e., involvement with charitable organizations) has measurement error as such involvement could be associated with the other CEO personal characteristics and firm characteristics. To alleviate this concern, we control for a variety of CEO and firm characteristics. While certain personal characteristics such as CEO ability and energy could potentially drive our results, to the extent that these characteristics affect not only charitable, but also non-charitable activities, controlling for non-charitable activities helps to rule out this alternative explanation. Moreover, we find that executive subordinate turnover, employee friendly policies and customer satisfaction are only significantly associated with CEO involvement with charitable organizations, but not with non-charitable organizations. This finding is consistent with CEO involvement with charitable organizations capturing their prosocial tendency. Finally, our CEO turnover analyses help to control for stable 
underlying firm characteristics since these characteristics will not lead to changes in corporate policies around CEO turnovers. ${ }^{6}$

Our study makes two important contributions to the literature. First, we contribute to the literature on prosocial behavior. Prosocial tendency is a fundamental aspect of human nature, affecting how individuals interact with others in the society (Batson and Powell, 2003). Primarily using surveys and experiments, research in sociology, psychology and economics has extensively investigated the incentives behind prosocial behavior and its benefits to individuals, including psychological and physical well-being (Sen, 1977; Meier and Stutzer, 2008; Wilson, 2012). We add to this literature by documenting the economic effects of prosocial behavior. Specifically, our findings indicate that individuals' prosocial tendency can benefit their career development and influence the decisions they make in their jobs. In addition, we develop a new measure of prosocial behavior using executives' involvement with charitable organizations, which allows researchers to study the determinants and consequences of individual prosocial behavior for a large sample.

Second, we contribute to the literature that examines individual executives' effects on corporate policies. Recent literature goes beyond traditional economic determinants of corporate policies and establishes that personal characteristics of executives play an important role in shaping firm policies (e.g., Bertrand and Schoar, 2003). We extend this line of research by examining a new characteristic of executives - prosocial tendency, which reflects our regard for other people and issues in the society we live in (Batson and Powell, 2003). Our results suggest that CEOs' prosocial tendencies have broad and significant effects on the welfare of various firm stakeholders.

\footnotetext{
${ }^{6}$ It is possible that firms choose CEOs based on their prosocial tendency to meet firms' needs for certain corporate policies (e.g., CSR policies). The inclusion of time-varying control variables in addition to year and industry fixed effects in our regressions helps to alleviate this concern. More importantly, even under this explanation, the fact that the board chooses CEOs with prosocial tendencies to meet firms' needs suggests that at least the board believes CEOs' prosocial tendency still matters for firms' corporate policies.
} 


\section{Literature Review and Hypothesis Development}

\subsection{Literature on prosocial behavior}

In this section, we review the literature on prosocial behavior, including its definition, determinants, and consequences. Prosocial behavior is broadly defined as acts that are perceived to primarily benefit others (Penner, Dovidio, Piliavin, and Schroeder, 2005). Prior studies have identified three non-mutually exclusive motivations underlying prosocial behavior: increasing others' well-being (i.e., altruism), concerns for social reputation, and financial rewards (Bénabou and Tirole, 2006; Carpenter and Myers, 2010).

Prosocial behavior could be driven by altruism; that is, an individual being willing to increase others' consumption by using her own financial or nonfinancial resources (Becker, 1976). Altruistic individuals engage in prosocial behavior because they care for the well-being of others. Evidence from research in economics, sociology and biology suggests that altruism exists and is a fundamental aspect of human nature (Piliavin and Charng, 1990; Meier, 2006). Further, levels of altruism vary across humans and can be developed either genetically or through early childhood experience, indicating that altruism is a fairly stable personal characteristic. Next, incentives to build social reputation can also lead to prosocial behavior. Specifically, prosocial behavior might reflect a desire to portray the image of being a "good" person. For example, individuals may behave prosocially to gain social approval for their behavior and to reap the resulting benefits from such approval (Akerlof, 1980; Bénabou and Tirole, 2006; Ellingsen and Johannesson, 2007). Nevertheless, motivations stemming from social reputation also drive people to consider others' needs and engage in behavior to meet those needs. Finally, individuals may engage in prosocial behavior to gain financial rewards, particularly indirect ones (Bénabou and Tirole, 2006). For example, people who have been out of the labor market due to illness or childbearing may volunteer in order to rebuild skills and reenter the labor market (e.g. Meier and Stutzer, 2008). 
In terms of the consequences of prosocial behavior, prior research has mostly used an experimental or survey approach to understand the psychological and emotional benefits of donation, volunteer work or helping behavior. In general, the results of these studies indicate that such behavior leads to greater psychological well-being, such as happiness, life satisfaction and confidence (Musick and Wilson, 2003; Lyubomirsky, Tkach, and Sheldon, 2004; Dunn, Aknin, and Norton, 2008; Mellor et al., 2012). For example, Dunn, Aknin, and Norton (2008) find in a survey and field study that people who spend more of their income on others experience greater happiness. Besides monetary giving, prior studies have also found that volunteering and committing acts of kindness can increase happiness. For example, using large-scale survey data, Meier and Stutzer (2008) find that volunteers experience greater life satisfaction than nonvolunteers.

Studies have also found that prosocial behavior can benefit individuals' social networks, job productivity, and reputation amongst colleagues. Engaging in volunteer work can increase individuals' likelihood of gathering useful information and help individuals develop social contacts that benefit their career and business (Musick and Wilson, 2003; Meier and Stutzer, 2008). In addition, prosocial activities such as volunteering likely offer opportunities for people to develop and improve various work-related skills, including team building, communication, and interpersonal skills (Rodell, Breitsohl, Schröder, and Keating, 2016). Prior research has also proposed that individuals' personalities are enhanced as they participate in multiple roles because they learn to be tolerant of discrepant views and be flexible in adjusting to different situations (Sieber, 1974; Marks, 1977). Finally, Blau (1964) and Flynn (2003) show that more generous individuals have better reputation amongst their co-workers. Taken together, the findings of prior studies suggest that engaging in prosocial activities outside of one's main job has psychological and emotional benefits (e.g., increased happiness) and work-related benefits (e.g., improved social 
connections and skillsets). However, as far as we know, no prior studies have examined whether an individual's prosocial tendency relates to her career development and on-the-job decision making. This study fills this gap by focusing on CEOs.

\subsection{Hypothesis development}

\subsubsection{Prosocial behavior and CEO careers}

Prosocial behavior can benefit individuals' career development for three possible reasons.

First, prosocial behavior such as charitable giving or volunteering leads to happiness, selfconfidence, and other positive emotions at the individual level (Dunn, Aknin, and Norton, 2008; Anik, Aknin, Norton, and Dunn, 2009; Midlarsky, 1991), which psychology studies show improve productivity (e.g., Achor, 2011). As an example, Rodell (2013) finds in two field studies that employees who volunteer tend to have improved concentration at work, leading to better job performance. The better job performance driven by prosocial behavior could in turn increase the likelihood of promotion.

Second, prosocial behavior is likely to expand one's skillset for career development (e.g., interpersonal skills). These effects are the result of positive synergies between individuals' offthe-job prosocial activities and on-the-job performance (Marks, 1977; Musick and Wilson, 2003; Rodell, Breitsohl, Schröder, and Keating, 2016). For example, sociology theory predicts that participation in activities outside one's main job can be beneficial in helping individuals learn to adapt quickly to different situations, and to improve communication and coordination skills (Sieber, 1974).

Third, prosocial behavior can help individuals to build trust with their colleagues and expand their social network outside the organization, which in turn could benefit their career development (e.g., Blau, 1964; Flynn, 2003). Because prosocial people tend to consider others' needs, they are more likely to cooperate with colleagues rather than shirk or free-ride, which 
enables them to build trust (e.g., Katz and Rosenberg, 2005; Whitener, Brodt, Korsgaard, and Werner, 1998). Such trust would facilitate communication and enhance cooperation among their team, which are critical for leadership and career progression. In addition, to the extent that otherregarding preferences are associated with the willingness to understand others' feelings, thoughts and behavior, prosocial individuals are likely to have higher emotional intelligence, which is a key leader attribute (e.g., Zaccaro, Banks, Kiechel-Koles, Kemp, and Bader, 2009). Thus, we expect that prosocial behavior helps to build and improve one's relationship with others and positively impacts one's career.

On the other hand, prosocial activities might harm a manager's career development since these activities take time and effort. The scarcity view in sociology studies suggests that multiple roles create strain on individuals; people do not have enough energy for multiple roles and thus may have to make compromises (Goode, 1960). Following this line of reasoning, prosocial behavior could dilute managers' focus on their job responsibilities and hinder their ability to do their jobs effectively. Given that there is no clear ex ante prediction on the relation between prosocial behavior and career success, we state our first hypothesis in null form:

H1: Prosocial behavior is not associated with the time it takes for an individual to become a CEO.

\subsubsection{Prosocial CEOs and corporate policies}

Since a prosocial individual is more likely to have other-regarding preferences, once she becomes a CEO, she is likely to treat and interact with employees, customers, shareholders, and other societal members differently from a non-prosocial CEO. As suggested in the management literature, CEOs' personal values influence their firms' decision-making processes (Wally and Baum, 1994). With respect to CEOs' direct subordinates, we expect prosocial leadership to be associated with lower executive subordinate turnover. Executive subordinates differ from other 
employees in that they interact with the CEO frequently, which allows them to understand the CEO's personality and management style. Prosocial CEOs' tendency to consider subordinates' needs likely facilitates developing and sustaining goodwill with them. Prior research has shown that leaders who are willing to incur personal costs to serve the goals of a group are perceived more positively by their subordinates (Van Knippenberg and Van Knippenberg, 2005; De Cremer and Van Knippenberg, 2004). Moreover, Haynes, Josefy, and Hitt (2015) propose that CEOs who show a high concern for others actively share information with subordinates and are able to maintain effective relationships with them. Therefore, we expect that prosocial CEOs are more likely to establish a trustworthy working relationship with subordinates, which leads to a lower executive subordinate turnover. ${ }^{7}$ Consistent with this conjecture, Kachaner, Stalk, and Bloch (2012) find that employee retention rates are significantly higher for family firms than non-family firms, partially due to a family-oriented culture and a willingness to invest in employees.

In addition to how prosocial CEOs treat their direct subordinates, we investigate how prosocial CEOs treat employees, including rank-and-file employees. Since prosocial CEOs tend to be concerned about others' well-being, we expect them to be more likely to establish corporate policies that take employees' well-being into consideration (e.g., strong retirement benefits or generous maternity policies). Therefore, we state our second hypothesis in alternative form as the following:

H2a: Non-CEO executives are less likely to leave firms with prosocial CEOs than firms with non-prosocial CEOs.

H2b: Firms with prosocial CEOs implement more employee-friendly corporate policies than firms with non-prosocial CEOs.

\footnotetext{
${ }^{7}$ We do not have a directional prediction for the association between prosocial leadership and performance-based subordinate turnover. On one hand, prosocial CEOs might be more likely to focus on firm goals and display less favoritism, which will lead to more performance-based subordinate turnover. On the other hand, firms with prosocial CEOs might have more generous employee policies that protect employees, which would reduce performance-based subordinate turnover.
} 
Note that these hypotheses are not without tension. Prior studies have found that employee welfare and satisfaction is positively associated with long-run stock performance and firm value (e.g., Edmans, 2008; Jiao, 2010). To the extent that non-prosocial CEOs are incentivized to maximize firm value due to compensation and career concerns, non-prosocial CEOs may also treat their subordinates well and have employee-friendly policies. Under this argument, we would expect no difference in CEO subordinate turnover and employee-friendly corporate policies between firms with prosocial and non-prosocial CEOs.

Other than employees of the firm, we also expect prosocial CEOs to display more consideration for customers. Prior research has shown that CEOs have a direct influence on firmcustomer relationships and overall customer satisfaction (e.g., Luo, Wieseke, and Homburg, 2012; Luo, Kanuri, and Andrews, 2014). Prosocial CEOs are likely more willing to invest resources to build firm-customer relationships, and less willing to extract short term rents from customers through increasing product pricing or decreasing product quality. Haynes, Josefy, and Hitt (2015) also propose that CEOs who are concerned for others' well-being are more likely to consider the effect of firm actions on customers by influencing product pricing, investment in customer service quality, and product control. ${ }^{8}$ Such influence likely leads to higher customer satisfaction. As a result, we expect that firms with prosocial CEOs have higher customer satisfaction. ${ }^{9}$ We state our third hypothesis in alternative form as the following:

\section{H3: Firms with prosocial CEOs have higher customer satisfaction than firms with non- prosocial CEOs.}

Finally, we consider how prosocial CEOs engage in overall CSR activities. Following prior

\footnotetext{
${ }^{8}$ Haynes, Josefy, and Hitt (2015) is a thought piece that does not provide empirical evidence.

${ }^{9}$ Prior research has documented mixed evidence on the association between customer satisfaction and firm financial performance (e.g., Ittner and Larcker, 1998; Luo and Homburg, 2007). Therefore, it is unclear if CEOs' incentives to maximize firm value due to compensation or career concerns complicate the association between CEOs' prosocial tendencies and customer satisfaction. The same applies to socially responsible activities given mixed prior evidence on the relation between CSR and firm performance (Waddock and Graves, 1997; Lys, Naughton, and Wang, 2015).
} 
literature (e.g., McWilliams and Siegel, 2001; Dhaliwal, Li, Tsang, and Yang, 2011; Lys, Naughton, and Wang, 2015; Cronqvist and Yu, 2017), we define CSR as instances where a firm voluntarily engages in actions and makes decisions that advance social causes and that benefit the society and stakeholders other than their shareholders. These actions could involve committing to environmental protection, improving product safety, and providing community support. Since prosocial individuals tend to consider others' well-being, we expect that prosocial CEOs are more willing to spend resources on their firm's social responsibilities. ${ }^{10}$ We state our fourth hypothesis in alternative form as the following:

H4: Firms with prosocial CEOs engage in more socially responsible activities than firms with non-prosocial CEOs.

\subsubsection{Prosocial CEOs and firm value}

Finally, an important question is whether it is beneficial for shareholders to have a prosocial CEO. On the one hand, a CEO acts as an agent of shareholders. To the extent that a prosocial CEO cares more about shareholders' interests than a non-prosocial CEO, she is less likely to sacrifice shareholders' interests to maximize her own utility, leading to fewer agency problems such as shirking and asset expropriation. Fewer agency problems likely result in better firm performance and an increase in firm value (Jensen and Meckling, 1976). On the other hand, prosocial activities require time and energy from CEOs, which may dilute CEOs' focus on their jobs and thus negatively impact firm performance and value.

In addition, CEOs prosocial tendency may relate to firm performance and value indirectly through their influence on corporate policies. Specifically, prior studies find that employee-related CSR is positively associated with firm performance and value (Edmans, 2008; Jiao, 2010). If

\footnotetext{
${ }^{10}$ Consistent with this argument, based on a survey of 80 CEOs, Agle, Mitchell, and Sonnenfeld (1999) document a positive univariate association between CEOs' other-regarding values and the community aspect of CSR performance.
} 
prosocial CEOs improve employee welfare, we expect that prosocial CEOs also improve firm performance through implementing more employee-friendly policies. However, since evidence on the associations of firm performance with customer satisfaction and corporate social responsibility is largely mixed, it is unclear how prosocial CEOs' corporate policies on customer satisfaction and corporate social responsibility affects firm performance. Taken together, ex ante, it is not clear how CEOs' prosocial tendency is associated with firm value and performance. Hence, we state our last hypothesis in the null form:

H5: CEOs' prosocial tendency is not associated with their firm value and performance.

\section{Data on CEOs' prosocial behavior and their career paths}

Using BoardEx database, we identify 71,658 individuals who first became CEOs at either private or public companies from 1950 to May $2019 .{ }^{11}$ For these individuals, we determine their involvement with charitable organizations in two steps. First, we obtain from BoardEx their memberships and involvement at various off-the-job organizations, including leisure clubs, professional organizations and charitable organizations. ${ }^{12}$ Second, we match these organizations' names with charitable organizations classified by IRS. ${ }^{13}$ If an individual has been involved with at least one charitable organization during her career, we identify her as prosocial, for whom a

\footnotetext{
${ }^{11}$ We downloaded BoardEx data in May 2019 and thus our measure for charity involvement is till May 2019.

${ }^{12}$ BoardEx's data sources include company websites for public, private, and not-for-profit organizations, annual reports and accounts, companies' public filings, and select news outlets. To the extent that the data is partially based on managers' own disclosure on their involvement in charitable activities and the disclosure is possibly driven by the managers' desire to promote themselves, it should bias against finding our results as these managers are less likely to care about employees, customers or corporate social responsibilities. In addition, we find that the number of a manager's social activities captured by BoardEx is significantly and positively correlated with the duration of BoardEx's coverage of the manager. As a robustness check, we include the duration of BoardEx's coverage of the manager as an additional control in all our regression analyses. Our results do not change qualitatively and our inferences remain the same.

${ }^{13}$ IRS lists all tax exempt organizations in the Exempt Organizations Business Master File Extract, which can be downloaded at https://www.irs.gov/charities-non-profits/exempt-organizations-business-master-file-extract-eo-bmf. A sub-category of tax exempt organizations is "Charitable Organizations" (subsection code 03 and classification code 1 in the Exempt Organizations Business Master File Extract). For more information on IRS classifications, see https://www.irs.gov/pub/irs-soi/eo_info.pdf.
} 
variable, Charity, equals one. ${ }^{14,15}$ We define NonCharity equal to one if an individual has been involved with at least one non-charitable organization during her career. While Charity is our main treatment variable, we control for NonCharity in all our analyses to alleviate the concern that individuals get involved with charitable organizations due to high ability or high energy instead of prosocial tendency. Because BoardEx does not provide data on the timing of individuals' involvement with charitable organizations for most individuals, our Charity and NonCharity variables are individual specific and time-invariant. Prior research (e.g., Eisenberg et al. 2002; Penner, Dovidio, Piliavin, and Schroeder, 2005) has documented that prosocial tendency is significantly affected by individual personality, suggesting that prosocial preferences should be stable over time at least to some extent. ${ }^{16}$

To test whether prosocial tendency affects an individual's career progression, we measure the time taken for an individual to become a CEO (TimeToCEO) as the year difference between when an individual first becomes a CEO and when she starts her career. We use an individual's employment history from BoardEx to determine the year when she first becomes a CEO. Following Schoar and Zuo (2017), we obtain each individual's birth year from BoardEx and use

\footnotetext{
${ }^{14}$ Examples of charitable organizations in our sample include American Cancer Society, Big Brothers Big Sisters of America, United Way Inc., Habitat for Humanity, Teach for America, American Diabetes Association, the YMCA, American Heart Association, American Council on Education, and Leukaemia and Lymphoma Society.

${ }^{15}$ One potential concern is that the involvement of charity work may also capture an individual's narcissism. A narcissistic person may participate in charitable organizations just to show their superiority relative to others. Empirically, we do not find significant associations between our prosocial measure, Charity, and narcissism measures in prior studies which are based on CEO's relative cash to noncash pay and the prominence of their photograph in the annual report (e.g., Olsen and Stekelberg, 2016; Judd, Olsen, and Stekelberg, 2017). Therefore, it is unlikely that Charity proxies for narcissism. We would like to thank Kari Olsen for sharing his data on CEO narcissism.

${ }^{16}$ For example, Penner, Dovidio, Piliavin, and Schroeder (2005) state "these [prosocial] tendencies are relatively stable across a person's life" (p. 375). Moreover, Batson and Powell (2003), when reviewing prosocial literature, state that dispositional factors, which tend to be stable, can predict the higher cost, nonspontaneous and long-term prosocial behavior more accurately than other types of prosocial behavior. CEOs' prosocial behavior we examine likely has higher cost and longer-term involvement as the common positions that the CEOs hold in charitable organizations include directors, trustees, (vice) chairman, (vice) president and advisory board members. CEOs are unlikely to hold these positions spontaneously and the positions typically last at least several years.
} 
the age of 24 as her career starting year. ${ }^{17} \mathrm{We}$ obtain other control variables on CEOs' demographic information from BoardEx. After removing individuals that do not have necessary data, we have a final sample of 41,205 individuals. Among them, 3,548 individuals became CEOs of public firms from 1950 to May 2019. ${ }^{18}$

\section{Empirical Results}

\subsection{Testing H1 - Prosocial CEOs and their careers}

To test H1, we perform an OLS regression of the time taken to be promoted to a CEO (TimeToCEO) on the indicator variable for charity involvement (Charity):

$$
\begin{aligned}
\text { TimeToCEO }_{i}= & \beta_{0}+\beta_{1} \text { Charity }_{i}+\beta_{2} \text { NonCharity }_{i}+\beta_{3} \text { Woman }_{i}+\beta_{4} \text { MBA } A_{i}+ \\
& \beta_{5} \text { Grad_Law }_{i}+\beta_{6} \text { CPA }_{i}+\beta_{7} \text { Auditor }_{i}+\beta_{8} \text { Consultant }_{i}+\beta_{9} \text { Banking }_{i}+ \\
& \beta_{10} \text { Legal }_{i}+\beta_{11} \text { Investment }_{i}+\beta_{12} \text { PriorJobs }_{i}+\beta_{13} \text { Log_Network }_{i}+ \\
& \beta_{14} \text { Log_AT }_{i, j, t-1}+\beta_{15} \text { MT }_{i, j, t-1}+\beta_{16} \text { Leverage }_{i, j, t-1}+ \\
& \text { Industry fixed effects }+ \text { StartYear fixed effects }+\varepsilon
\end{aligned}
$$

As discussed above, TimeToCEO is the number of years individual $i$ takes to become a CEO from the beginning of her career. Charity is an indicator variable for the individual's charity involvement, while NonCharity is an indicator variable for her non-charity involvement. We control for personal characteristics and background as well as firm characteristics following Schoar and Zuo (2017). For personal characteristics, we include CEO gender (Woman), whether she earned an MBA degree (MBA), whether she holds a Juris Doctorate degree (Grad_Law), and whether she is a CPA $(C P A)$. We also control for professional experience before becoming CEO. Specifically, we identify if individual $i$ worked as an auditor or a consultant, and whether she had

\footnotetext{
${ }^{17}$ This empirical strategy helps us to address the endogenous choices that individuals make in terms of when to start their career. For example, individuals may choose to accelerate or delay the start of their career depending on the economic conditions in that year, which also affect the time they take to become CEOs (Schoar and Zuo, 2017). The age of 24 is also the mean and median age to start the first job for CEOs in our sample. As a robustness check, we use individuals' bachelor or Juris Doctorate graduation year as their career starting year to calculate TimeToCEO for the sample where such information is available. Our results do not change qualitatively.

${ }^{18}$ We discuss the other databases we use and the related variable definitions in Section 4.
} 
working experience in banking, legal, and investment industries before she became a CEO. We also construct a variable to capture individual $i$ 's job stability, PriorJobs, which is the first principal component of the number of industries, firms, and business positions the individual was employed in or held before becoming CEO. Finally, we control for the total number of the individual's social connections via education, working experience and other activities before she became a CEO (Log_Network), as prior research shows that managers' social network affects their value in labor market (e.g., Engelberg, Gao, and Parsons, 2013).

In addition, the type of the firm that an individual works for may affect how soon she becomes CEO. Assume individual $i$ became a CEO for the first time at firm $j$ in year t. We control for firm size using the natural logarithm of total assets $\left(\log _{-} A T\right)$, market to book ratio $(M T B)$, and leverage (Leverage) in the year before she became the CEO (year $t-1$ ). Due to data availability constraints, we can only obtain these variables for public firms. We also control for industry fixed effects because the time taken to be promoted to the CEO position might differ across industries. ${ }^{19}$ Start-year fixed effects are included to control for the effect of economic conditions during the year an individual starts her career on her career outcomes (Schoar and Zuo, 2017).

Table 1, Panel A presents the descriptive statistics for variables used in testing H1. We find that $28.2 \%(56.1 \%)$ of CEOs in our sample are involved with at least one charitable (non-charitable) organization. The average time taken to become a CEO of any type of firm is 22.16 years, whereas it takes 26.29 years to become a CEO of a public firm. With respect to CEOs' personal backgrounds, $5.5 \%$ of all the individuals who become a CEO are female, $26.0 \%$ of them hold MBA

\footnotetext{
${ }^{19}$ When we examine the time taken to become CEO of any type of firm, industry fixed effects are based on BoardEx's industry classification since many firms are private firms and their SIC codes are not available. When we examine the time taken to become a public firm's CEO, we construct industry fixed effects based on two-digit SIC code to match with all the other analyses in the paper.
} 
degrees, and $6.5 \%$ of them have CPA license. ${ }^{20}$ Detailed definitions of all variables are in the Appendix. Panel B of Table 1 presents Pearson (above the diagonal) and Spearman (below the diagonal) correlations between these variables. Charity and NonCharity are either insignificantly or slightly positively related to TimeToCEO, and many control variables are significantly correlated with both Charity and TimeToCEO. For example, having an MBA is negatively associated with TimeToCEO and is also positively associated with Charity. Additionally, Charity and NonCharity are positively correlated. This correlation matrix highlights the importance of conducting multivariate regressions and controlling for non-charity involvement and other variables in our analyses.

Table 2 presents regression results from the estimation of equation (1). In Column (1), we examine the time it takes for an individual to become CEO of any type of firm. In Column (2), we focus on individuals who become $\mathrm{CEO}$ of a public firm during our sample period. The coefficients on Charity in these two columns are both negative and significant $(\mathrm{p}<0.001)$, suggesting that prosocial individuals take a shorter time to be promoted to CEO. Economically, on average, prosocial individuals are promoted to CEO of any type of firm 1.398 years faster and CEO of a public firm 1.038 years faster than non-prosocial individuals. Since it takes about 22 (26) years for an individual to be promoted to a CEO (of a public firm) on average, these economic magnitudes are considerable. $^{21}$

For control variables, we find that participating in non-charitable activities also improves

\footnotetext{
${ }^{20}$ Untabulated results show that compared with individuals who become CEO of private firms, individuals who become CEO of public firms are more likely to hold a MBA, law degree and CPA, are more likely to have auditor experience, are less likely to work in banking and legal industries, move across more industries/firms before becoming public firms' CEO, and have larger network.

${ }^{21}$ An individual may be more likely to be invited to join a charitable organization once she becomes a CEO, leading to a positive association between CEO position and charitable organization involvement. This is why we do not investigate whether charitable organization involvement increases the chance an individual becomes a CEO. This possibility, however, unlikely biases for our finding that charitable organization involvement is significantly associated with TimeToCEO conditional on an individual becoming a CEO or with the CEO's corporate policies.
} 
career progression, as evidenced by the negative and significant coefficient on NonCharity. This result is consistent with non-charity involvement capturing individual characteristics such as ability or energy. We also find that it takes longer for females (Woman) and individuals with CPA $(C P A)$ to reach the CEO position. In addition, managers with consultant experience, banking industry experience, or investment firm experience get promoted to the CEO position earlier. We find that PriorJobs is significantly and positively associated with the time taken to be promoted to a CEO. This finding suggests that it takes longer for individuals who switch between more jobs to become CEO. We also notice that it takes longer for an individual to become a CEO if she has more social connections (Log_Network). One possible reason is that managers who have more advanced degrees tend to have more social connections through education institutes. These individuals most likely started their career later and subsequently become a CEO later. When we control for firm characteristics in Column (2), we find that it takes longer for an individual to become CEO of a larger firm, and a firm with less growth opportunities and higher leverage.

\subsection{Testing H2 - Prosocial CEOs and employees}

\subsubsection{Executive subordinates' turnover}

To test $\mathrm{H} 2 \mathrm{a}$ that subordinates of a prosocial $\mathrm{CEO}$ are less likely to leave the firm, we focus on turnover of the top four executives other than the CEO. For each firm year, we identify the top four executives as the four highest paid executive subordinates based on their total annual compensation, which we obtain from ExecuComp and BoardEx. ${ }^{22}$ We then obtain each executive subordinate's leaving date from the BoardEx employment file and use data from ExecuComp as a supplement. If neither database provides a subordinate's specific leaving date from a firm, we assume that the subordinate left the firm when she is no longer listed as an executive in the

\footnotetext{
${ }^{22}$ We begin with using ExecuComp to identify subordinates' compensation. For firm-years with no data in Execucomp, we use BoardEx.
} 
subsequent two years in ExecuComp. ${ }^{23}$ For each subordinate-firm-year, we construct an indicator variable, Turnover, that is equal to one if the subordinate leaves the firm in the following year and zero otherwise. In addition, we set the Turnover indicator to zero if a subordinate is above 65 years old when she leaves the company as she probably retired rather than switched jobs (e.g. Cheng, Lee, and Shevlin 2016). Our final sample for testing H2a consists of 108,464 subordinate-firmyear observations across 2,570 firms and 32,844 firm-years for the period of 1992-2018. ${ }^{24}$

We use the following linear probability model to examine the association between subordinate turnover and CEO charity involvement $(\mathrm{H} 2 \mathrm{a}):^{25}$

$$
\begin{aligned}
\text { Turnover }_{i, j, t+1}= & \beta_{0}+\beta_{1} \text { Charity }_{j, t}+\beta_{2} \text { NonCharity }_{j, t}+\beta_{3} \text { Log_AT }_{j, t}+\beta_{4} \text { MTB }_{j, t}+ \\
& \beta_{5} \text { Leverage }_{j, t}+\beta_{6} \text { ROA }_{j, t}+\beta_{7} \text { SizeAdjRet }_{j, t}+\beta_{8} \text { CEOAge }_{j, t}+ \\
& \beta_{9} \text { CEOTenure }_{j, t}+\beta_{10} \text { InternalCEO }_{j, t}+\beta_{11} \text { CEO_Leave }_{j, t}+ \\
& \beta_{12} \text { SubordinateAge }_{i, t}+\beta_{13} \text { SubordinateTenure }_{i, j, t}+ \\
& \beta_{14} \text { SubordinateAge }_{i, t}+\beta_{15} \text { SubordinateTenure }_{i, j, t}+ \\
& \beta_{16} \text { Subor_PercShrsOwn }_{i, j, t}+\text { Industry fixed effects }_{+}+\varepsilon
\end{aligned}
$$

Turnover $_{i, j, t+1}$ equals one if subordinate $i$ leaves firm $j$ in year $t+1$ and zero otherwise. Charity $y_{j, t}$ (NonCharity $y_{j, t}$ ) equals one if the CEO of firm $j$ in year $t$ is involved with charitable (non-charitable) organizations and zero otherwise. Following Hayes, Oyer, and Schafer (2006), we include firm, $\mathrm{CEO}$, and subordinate-level controls that may affect the likelihood of subordinate turnover. At the firm-year level, we control for firm size (Log_AT), growth (MTB), leverage (Leverage), and firm performance (ROA and SizeAdjRet). We also control for CEO age (CEOAge), CEO tenure (CEOTenure), whether the CEO is internally promoted or externally hired (InternalCEO), and whether the CEO leaves the firm in year $t$ (CEOLeave). Further, we control for subordinate

\footnotetext{
${ }^{23}$ We validate this assumption using subordinates who are not listed as an executive in the subsequent two years in ExecuComp, but whose employment history can be found in BoardEx. We find that $70 \%$ of these subordinates leave the firm in the year when they drop off from the top executives list in ExecuComp, consistent with our assumption.

${ }^{24}$ Our sample period for testing H2-H5 begins with 1992 because ExecuComp starts in 1992.

${ }^{25}$ Following prior studies (e.g., Cornelli, Kominek, and Ljungqvist, 2012; Guo and Masulis 2015), we report a linear probability model instead of a non-linear logit or probit model because it is easier to implement fixed effects and interpret coefficients. As a robustness check, we also estimate this regression with logit specification and find qualitatively similar results.
} 
characteristics that may affect their decisions to leave the firm, including subordinate age (SubordinateAge), tenure at the firm (SubordinateTenure), and percentage of the firm's common stock owned by the subordinate (Subor_PercShrsOwn). Since the relation between a subordinate's mobility and her age and tenure are likely non-linear (Avolio, Waldman, and Mcdaniel, 1990), we add square terms of the subordinate's age and tenure. Finally, we include industry fixed effects and cluster standard errors by firm in this and all subsequent regression analyses.

Panel A of Table 3 presents descriptive statistics, which are comparable with prior studies (e.g. Hayes, Oyer, and Schafer, 2006). Panel B reports results from the estimation of equation (2). In Column (1), we use all subordinate-firm-years. The coefficient on Charity is insignificant, suggesting prosocial CEOs are not associated with subordinate turnover. One possible reason is that subordinates who are older and closer to retirement have less career mobility, and thus are less likely to leave their firm, regardless of their CEOs' prosocial tendency. Consistent with this conjecture, we find that among subordinates leaving their current firms, $89.5 \%$ of subordinates who are younger than 50 years old join another firm after they leave while only $7 \%$ of subordinates aged 50 and above move to a different firm after leaving (untabulated). Therefore, we split our sample into two subsamples of subordinates aged above and below 50.

Column (2) of Table 3 Panel B reports the results for the subsample of subordinates who are aged below 50. The coefficient on Charity is significantly negative, consistent with our prediction that subordinates of a prosocial CEO are less likely to leave the firm. Specifically, for executive subordinates below the age of 50, having a prosocial CEO reduces their likelihood of leaving the firm by $1.3 \%$, which is economically meaningful given the average subordinate turnover rate in our sample of $17.5 \%$. In contrast, the coefficient on NonCharity is insignificant, which strengthens our inference that the association between Charity and executive subordinate turnover is not driven by CEO involvement in general off-the-job activities, but by their prosocial 
tendency. In Column (3), we estimate the same regression on the subsample of subordinates aged 50 and above and find that the coefficient on Charity is insignificant. ${ }^{26}$

Although the results discussed above are consistent with $\mathrm{H} 2 \mathrm{a}$, one alternative explanation is that the negative association between prosocial CEOs and subordinate turnover is driven by underlying firm characteristics. For example, a company with a more friendly corporate culture may be more likely to both hire a prosocial CEO and implement more employee-friendly corporate policies, leading to lower subordinate turnover. To address this concern, we investigate whether a change in CEO prosocial type is associated with a change in subordinate turnover using a sample of firms with CEO turnovers. To the extent that firm characteristics do not change significantly around a CEO turnover, the change in subordinate turnover in this subsample is more likely driven by the change in the CEO's prosocial type. Specifically, we estimate the following regression:

$$
\begin{aligned}
\text { Turnover }_{i, j, t+1}= & \beta_{0}+\beta_{1} \text { CharityImprove }_{j}+\beta_{2} \text { Post }_{j, t}+ \\
& \beta_{3} \text { CharityImprove }_{j} \times \text { Post }_{j, t}+\sum \text { Controls }+ \\
& \text { Industry fixed effects }+\varepsilon
\end{aligned}
$$

For firm $j$, Post $_{j, t}$ equals one if year $t$ is after a CEO turnover, and zero otherwise. Since Post can only be defined around one CEO turnover for each firm, we keep firms with only one CEO turnover during our sample period for this analysis. ${ }^{27}$ CharityImprove $_{j}$ equals one for all years of firm $j$ if its CEO turnover involves a replacement of a non-prosocial CEO with a prosocial CEO, and zero otherwise. The coefficient on CharityImprove $\left(\beta_{1}\right)$ represents the difference between average subordinate turnover before the CEO turnover for firms with CharityImprove equal to one and for firms with CharityImprove equal to zero. The coefficient on Post $\left(\beta_{2}\right)$ captures the

\footnotetext{
${ }^{26}$ A Wald chi-square test shows a significant difference between the coefficients on CharityCEO in Columns (2) and (3) $(\chi 2$-stat $=9.03$ with p-value $<0.01)$, confirming that prosocial CEOs have higher influence on the turnover rate of younger subordinates than older subordinates.

${ }^{27}$ As a robustness check, we keep only the first CEO turnover for firms with more than one CEO turnover in the turnover sample and our results do not change qualitatively.
} 
difference between the average likelihood of subordinate turnover under the first CEO and that under the successor CEO for all firms with CharityImprove equal to zero. We interact CharityImprove and Post. The coefficient on the interaction $\left(\beta_{3}\right)$ captures the incremental change in subordinate turnover after the CEO turnover for firms with CharityImprove equal to one relative to other firms. If a prosocial CEO is better able to retain subordinates, the likelihood of a subordinate leaving a firm should decrease more or increase less after the CEO turnover for firms with CharityImprove equal to one than for other firms. We thus expect $\beta_{3}$ to be negative (H2a). We include the same control variables as those in equation 2) except for CEO_Leave as it always equals zero.

Column (4) of Table 3 Panel B presents results from the estimation of equation (3). The coefficient on Post is 0.006 and significant, suggesting that on average, executive subordinates are more likely to leave after a CEO turnover for firms with CharityImprove equal to zero. However, the coefficient on the interaction term, Post $\times$ CharityImprove, is -0.009 and significant. This result suggests that the executive subordinate turnover rate around the CEO turnover increases significantly less for firms replacing a non-prosocial CEO with a prosocial CEO than for other firms. Indeed, the net change in subordinate turnover for firms with CharityImprove equal to one is negative (0.006-0.009), suggesting that average subordinate turnover decreases after such CEO turnovers, but increases after other types of CEO turnovers (0.006). In sum, this analysis further strengthens our inference that prosocial CEOs improve executive subordinate retention, and that this effect is unlikely to be driven by the underlying firm characteristics.

Turning to control variables, we find that the coefficient on NonCharity is again negative and insignificant in Columns (1) - (3). We also find that the coefficient on Leverage is significantly positive, and that the coefficients on ROA and SizeAdjRet are both negative and significant. These results suggest that executive subordinates are more likely to leave firms with higher leverage and 
lower performance. CEOTenure and InternalCEO are negatively associated with turnover, suggesting that longer-tenured CEOs and internally promoted CEOs are better able to retain their direct subordinates. Further, we find that $C E O \_$Leave is positively associated with turnover in Column (1) - (3), which is consistent with prior studies and suggests that executive subordinates are more likely to leave right after their CEO leaves the firm (e.g., Hayes, Oyer, and Schaefer, 2006). Turning to subordinate characteristics, age and tenure at the firm are positively and negatively associated with the likelihood of leaving the firm respectively, and these associations are both nonlinear, as indicated by significant coefficients on squared age and squared tenure. Finally, the percentage of the firm's shares owned by the subordinate is negatively and significantly associated with subordinate turnover.

Overall, our evidence based on both full sample and the subsample with CEO turnovers is consistent with subordinates being less likely to leave when working for a prosocial CEO (H2a).

\subsubsection{Corporate policies on employee welfare}

$\mathrm{H} 2 \mathrm{~b}$ predicts that prosocial CEOs are more likely to establish corporate policies that take employees' well-being into consideration. We measure firms' policies on employee welfare using data from MSCI ESG KLD STATS, which assesses firms' social performance using a combination of surveys, financial statements, articles in the popular press and academic journals, and government reports. ${ }^{28}$ For each firm-year, the database assesses and reports strengths and concerns along various dimensions including corporate governance, community, diversity, employee relations, environment, and product. We calculate the KLD score on employee welfare, Employee_KLD, using total strengths minus total concerns in KLD's employee relations category

\footnotetext{
${ }^{28}$ Starting from 1991, KLD rated approximately 650 firms every year, comprising mainly all firms in the S\&P 500 and Domini 400 Social SM Index. During 2001 to 2002, KLD expanded its coverage to the largest 1,000 U.S. companies by market capitalization. Since 2003, it has covered the largest 3,000 U.S. firms based on market capitalization.
} 
where KLD assesses firms' union relations, no-layoff policy, cash profit-sharing plans, employee involvement, retirement benefits, policies on employee health and safety, professional development, etc. Our sample for testing H2b starts in 1992 and ends in 2016, which is the most recent year with available data in the MSCI ESG KLD STATS database. After removing firmyears that do not have KLD data, we are left with 20,597 firm-years. We estimate the following OLS regression to test $\mathrm{H} 2 \mathrm{~b}$ :

$$
\begin{aligned}
\text { Employee_KLD }_{j, t+1}= & \beta_{0}+\beta_{1} \text { Charity }_{j, t}+\beta_{2} \text { NonCharity }_{j, t}+\beta_{3} \text { Log }_{-} A T_{j, t}+ \\
& \beta_{4} \text { MTB }_{j, t}+\beta_{5} \text { Leverage }_{j, t}+\beta_{6} \text { ROA }_{j, t}+\beta_{7} \text { FirmAge }_{j, t}+ \\
& \beta_{8} \text { Cash }_{j, t}+\beta_{9} \text { CFO }_{j, t}+\beta_{10} R D_{j, t}+\beta_{11} \text { Advertising }_{j, t}+ \\
& \text { Industry fixed effects }+ \text { Year fixed effects }+\varepsilon
\end{aligned}
$$

We expect the coefficient on Charity to be significantly positive (H2b). We control for firm characteristics that likely affect a firm's overall CSR performance since policies on employee welfare is one dimension of CSR activities. Specifically, we control for firm size (Log_AT) since larger firms have more resources for CSR activities. We include growth (MTB), leverage (Leverage), and firm age (FirmAge) because stable and mature firms with lower risk are generally more likely to make CSR expenditures (Orlitzky and Benjamin, 2001). We control for firm performance (ROA), cash holdings (Cash), and cash flow from operations (CFO) because performance and cash flow affect both a company's ability and pressure from the community to conduct CSR activities (Campbell, 2007; Lys, Naughton, and Wang, 2015). We also include R\&D $(R D)$ and advertising expenditures (Advertising) since firms with a greater amount of such expenditures tend to invest more in CSR activities (McWilliams and Siegel, 2000; Wieser, 2005).

Table 4 presents the results from estimating equation (4). In Column (1), consistent with $\mathrm{H} 2 \mathrm{~b}$, we find that the coefficient on Charity is 0.047 and significant $(\mathrm{p}<0.10)$. Economically, relative to non-prosocial CEOs, prosocial CEOs improve a firm's employee relations KLD rating by 0.047 on average, which is a significant improvement when benchmarked against the mean 
Employee_KLD of 0.060 for our sample (untabulated). This result suggests that prosocial CEOs have a positive effect on corporate employee policies. In contrast, the coefficient on NonCharity is insignificant, suggesting that CEOs' participation in general off-the-job activities is not associated with their corporate employee policies.

Similar to the subordinate turnover analyses, to address the concern that the result in Column (1) is driven by underlying firm characteristics, we focus on the subsample of firm-years around CEO turnovers in Column (2). While the coefficient on Post is negative, the coefficient on CharityImprove $\times$ Post is significantly positive, suggesting that employee welfare decreases less when a prosocial CEO replaces a non-prosocial CEO than other types of CEO replacements.

Finally, the association between control variables and employee KLD scores are generally consistent with our expectations. We find that the coefficients on Log_AT and FirmAge are positive and significant, consistent with larger firms and more mature firms having more resources to invest in employee welfare and therefore achieve better employee CSR ratings. We also find that firms with lower advertising expenditures have higher employee CSR ratings.

Overall, the above results suggest that prosocial CEOs are associated lower executive subordinate turnover, and are more willing to invest in policies to improve employee welfare.

\subsection{Testing H3 - Prosocial CEOs and customer satisfaction}

$\mathrm{H} 3$ predicts that having a prosocial CEO is positively associated with customer satisfaction. We obtain customer satisfaction data from the American Customer Satisfaction Index (ACSI) database which covers more than 400 foreign and domestic firms with significant U.S. market share from all major economic sectors. Every year, the ACSI surveys approximately 50,000 customers about the products and services they use the most and estimates firm-level customer satisfaction scores on a scale of 0-100. The ACSI score, our measure of customer satisfaction (Cust_Satis), is a widely used measure of customer satisfaction by academics (e.g. Luo and 
Bhattacharya 2006; Malshe and Agarwal 2015; Lim, Tuli, and Grewal, 2020). After merging ACSI data with data on CEO and firm characteristics, we are left with 1,224 firm-year observations from 1995 to 2018. To test H3, we estimate the following OLS regression:

$$
\begin{aligned}
\text { Cust_Satis }_{j, t+1}= & \beta_{0}+\beta_{1} \text { Charity }_{j, t}+\beta_{2} \text { NonCharity }_{j, t}+\beta_{3} \text { CEOTenure }_{j, t}+ \\
& \beta_{4} \text { Log_AT }_{j, t}+\beta_{5} \text { MTB }_{j, t}+\beta_{6} \text { Leverage }_{j, t}+\beta_{7} \text { ROA }_{j, t}+ \\
& \beta_{8} \text { Advertising }_{j, t}+\beta_{9} \text { RevenueGrowth }_{j, t}+ \\
& \text { Industry fixed effects }+ \text { Year fixed effects }+\varepsilon
\end{aligned}
$$

We control for CEO tenure (CEOTenure) as a CEO's experience is associated with her market knowledge (Hambrick 2007). We also control for firm size ( $\left.\log _{-} A T\right)$, return on assets $(R O A)$, leverage (Leverage), growth (MTB), advertising expenditure (Advertising), and revenue growth (RevenueGrowth), as firm resources and performance could affect investment in customer relations (Luo, Kanuri, and Andrew, 2014).

Table 5 presents the results from estimating equation (4). In Column (1), consistent with H3, we find that the coefficient on Charity is 0.583 and significant $(p<0.10)$. This result indicates that having a prosocial CEO is positively associated with customer satisfaction in the next year. Meanwhile, the coefficient on NonCharity is insignificant, suggesting that CEO participation in non-charity activities is not associated with customer satisfaction. In Column (2), when we use the subsample of firms with CEO turnovers, the coefficient on Post is negative, but the coefficient on Post $\times$ CharityImprove is still positive and significant. This result shows that customer satisfaction decreases less when a prosocial CEO replaces a non-prosocial CEO than when there are other types of CEO replacements, which confirms our inference from Column (1). However, the magnitude of the results in both columns (0.583 and 1.458) is not economically significant when benchmarked against the sample average customer satisfaction score of 76.67 (untabulated). Therefore, our results suggest that prosocial CEOs have a positive, but economically small, impact on customer satisfaction. As for control variables, firms with higher leverage (Leverage), better 
performance (ROA), and more advertising expenditure (Advertising) tend to have higher customer satisfaction, consistent with prior studies (e.g., Luo, Kanuri, and Andrews, 2014).

\subsection{Testing H4 - Prosocial CEOs and overall CSR policies}

$\mathrm{H} 4$ predicts that prosocial CEOs are more willing to channel firm resources toward CSR activities, and therefore their firms will have better corporate social performance. Similar to H2b, we measure CSR performance using data from MSCI ESG KLD STATS and construct our dependent variable, Total_KLD, as the difference between total strengths minus total concerns in KLD's rating on corporate governance, community, diversity, employee relations, environment, and product. ${ }^{29}$ We follow the same regression specification as equation (4), but replace the dependent variable with Total_KLD.

Table 6 presents the results from this analysis. In Column (1), consistent with H4, we find that the coefficient on Charity is positive (0.160) and significant $(\mathrm{p}<0.01)$, suggesting that firms with prosocial CEOs have 0.160 higher total KLD scores on average. These magnitudes are economically significant since the average Total_KLD is 0.041 for all firm-years in our sample. In Column (2), when we analyze changes in KLD scores around CEO turnovers, the coefficient on Post $\times$ CharityImprove is positive and significant $(0.213$ with $\mathrm{p}<0.01) .{ }^{30}$ These results provide support for $\mathrm{H} 4$ that firms with prosocial CEOs are more likely to engage in CSR activities than other firms, and that this association is not driven by the underlying firm characteristics. ${ }^{31}$

\footnotetext{
${ }^{29} \mathrm{KLD}$ has also assessed firms in the areas of human rights and firearms since 2002. Since these two dimensions are not available before 2002, we exclude them when constructing total KLD scores. In addition, KLD does not evaluate the strength, but only the concerns in exclusionary screen categories including alcohol, gambling, military contracting, nuclear power, and tobacco. We do not consider these exclusionary categories when calculating KLD scores because CEOs have less discretion on these categories.

${ }^{30}$ When we exclude Employee_KLD from Total_KLD, we continue to find significantly positive coefficients on Charity and Post $\times$ CharityImprove, indicating that prosocial CEOs are not only more likely to implement employee friendly policies, but also other CSR activities.

${ }^{31}$ As a robustness check, we also measure CSR using ratings on firms' environmental, social and governance (ESG) performance provided by Sustainalytics Company from 2009 to 2018 . We replace KLD score in equation (4) with: a) a company's total ESG score, which is an aggregate of social, environment, and governance scores, or b) a
} 
In terms of control variables, we find that the coefficient on NonCharity in Column (1) is positive and significant, suggesting CEOs' participation in other off-the-job activities is also associated with higher CSR ratings. In addition, the coefficients on Log_AT, FirmAge, Cash and $R D$ are all positive and significant in both columns, which is generally consistent with what we observe in Table 4. We also find that past firm performance is negatively associated with CSR ratings (the coefficient on $R O A$ is negative). ${ }^{32}$

\subsection{Testing H5 - Prosocial CEOs and firm value}

To test our last hypothesis, we use all firm-years with available data on CEOs' charity involvement as well as firm value and performance from year 1992 to 2018 . We estimate the following model:

$$
\begin{aligned}
& \text { Value }_{j, t+1} \text { or Performance } \text { Pot }_{j+1}=\beta_{0}+\beta_{1} \text { Charity }_{j, t}+\beta_{2} \text { NonCharity }_{j, t}+\beta_{3} \text { Log }_{-} A T_{j, t}+ \\
& \beta_{4} M T B_{j, t}+\beta_{5} \text { Leverage }+\beta_{6} R D_{j, t}+\beta_{7} C A R_{j, t}+ \\
& \beta_{8} \text { ReturnVolatility }_{j, t}+\beta_{9} \text { Num_Analysts }_{j, t}+ \\
& \beta_{10} \text { Instown_Perc }_{j, t}+\beta_{11} \text { Value }_{j, t} \text { or Performance } \text { Port }_{j}+ \\
& \text { Industry fixed effects }+ \text { Year fixed effects }+\varepsilon \text { (6) }
\end{aligned}
$$

where Value represents Tobin's Q (TobinsQ) and Performance represents annual size-adjusted returns (SizeAdjRet) and ROA (ROA). We control for firm size ( $\left.\log \_A T\right)$, growth $(M T B)$, leverage (Leverage), $\mathrm{R} \& \mathrm{D}$ expenditure $(R D)$, return volatility during the year (ReturnVolatility), the number of analysts following the firm (Num_Analysts), and percentage of institutional ownership (Instown_perc). When Tobins $Q$ and ROA are the dependent variable, we also control for cumulative market-adjusted stock return $(C A R)$. In addition, we control for mean reversion of the dependent variables by including the corresponding dependent variable in year $t$.

company's social score. We continue to find a positive and significant correlation between prosocial CEOs and firm ESG scores.

${ }^{32}$ When we regress Total_KLD on ROA with industry fixed effects and year fixed effects, the association is significantly positive. The negative coefficient on ROA in Table 6 may be due to the correlations between ROA and other control variables such as Log_AT and CFO. 
Results from the estimation of equation (6) are presented in Table 7. In Panel A, we use all firm-years with available data and find that the coefficient on Charity is positive and significant across all three columns. These results suggest that having a prosocial CEO is positively associated with firm value and performance. However, the results are weaker when we focus on firms with CEO turnovers (Panel B). The coefficient on Post $\times$ CharityImprove is significantly positive $(\mathrm{p}<0.01)$ only for Tobins $Q$, suggesting that there is more improvement in Tobin's $\mathrm{Q}$ when a prosocial CEO replaces a non-prosocial CEO than when there are other types of CEO replacements. Overall, we find consistent evidence that having a prosocial CEO is positively associated with firm value, but weaker evidence for annual firm performance.

In sum, the results of our analyses are consistent with there being positive career outcomes for prosocial individuals. The results also support the notion that prosocial CEOs experience lower subordinate turnover, positively influence both firm corporate social performance and customer satisfaction, and increase firm value.

\section{Additional Analyses and Robustness Tests}

\subsection{Path analysis of how prosocial CEOs affect firm value}

Our evidence suggests that prosocial CEOs have effects on both corporate policies and firm value. Because corporate policies could affect firm value, in this section, we perform a path analysis to examine whether prosocial CEOs influence firm values directly and/or indirectly through corporate policies. Specifically, we estimate a structural equation model of prosocial CEOs' direct effect on firm value (Tobins $Q$ ) as well as their indirect effect through corporate policies on employee welfare (Employee_KLD), customer satisfaction (Cus_Satis), and overall CSR activities (Total_KLD). The structural equation model includes a regression of Tobins $Q$ on Charity and mediating variables that capture corporate polices (Employee_KLD,CUs_Satis, and 
Total_KLD) and regressions of these mediating variables on Charity. ${ }^{33}$

Table 8 reports the results of the path analysis. The direct coefficients of Charity on Tobins $Q$ are significantly positive in all three columns, indicating that prosocial CEOs have a direct effect on firm value that is not related to corporate policies we examine in this paper. The indirect effect of Charity on Tobins $Q$ is product of the effect of Charity on the mediating variables and the effect of the mediating variables on Tobins $Q$. The significance of the indirect effect is estimated using the Sobel (1982) test statistic. We find that Charity has significant indirect effects on Tobins $Q$ through Employee_KLD and Total_KLD, but not through Cus_Satis, suggesting that prosocial CEOs have a significant indirect effect on firm value through impacting firms' CSR policies. Taken together, these results suggest that prosocial CEOs affect firm value both directly and indirectly through CSR initiatives.

\subsection{Prosocial behavior and executive careers}

While we focus on CEOs in this study, it is also interesting to examine whether prosocial behavior is associated with general executive career paths. Thus, we also examine the time taken for an individual to reach the top management team. Due to the large heterogeneity of executive job titles across different firms, we focus on the most common top management positions: CEO, CFO, COO, and President. We obtain an individual's entire employment history from BoardEx and search through the job titles that these individuals have ever held to identify the first year in their career when they became a top executive of a company. Similar to our analysis for H1, we use the age of 24 as each individual's career starting year and count the number of years that she takes to being first named as a top management team member (denoted as TimeToTMT for any firm and TimeToTMT_Public for a public firm). We remove individuals who never became a top

\footnotetext{
${ }^{33}$ All control variables in equation (6) are included in the regression of Tobins $Q$ on Charity and all control variables in equation (4) (equation (5)) are included in the regression of Cus_Satis (Employee_KLD and Total_KLD) on Charity.
} 
executive and obtain 119,753 individuals who joined top management teams of any type of firm from 1950 to May 2019 and 11,466 individuals who became a top executive of a public firm.

We replace the dependent variable in equation (1) with TimeToTMT and re-run the regression. Table 9 presents the results for this analysis. We find that the coefficients on Charity in both columns are negative and significant, suggesting that prosocial individuals take a shorter time to reach a top executive position.

\subsection{Alternative measure of CEO's prosocial behavior}

In our analysis for $\mathrm{H} 1$, we use the indicator variable Charity to identify whether a CEO is prosocial. Another way to capture a CEO's prosocial tendency is to count the number of charitable organizations that she is involved in. Thus, to check the robustness of our results, we count both the number of charitable organizations and the number of non-charitable organizations a CEO is involved in and replace Charity and NonCharity with these measures respectively. Apart from customer satisfaction, all our results continue to hold in this set of analyses.

\section{Conclusion}

This study examines the relations between CEOs' prosocial behavior and their career and corporate policies. We develop a new measure of individual prosocial behavior using their off-thejob involvement with charitable organizations. We first show that individual prosocial behavior is negatively associated with the time taken to be promoted to the position of CEO, suggesting that individuals' prosocial tendency benefits their career advancement. We then examine the effects of having a prosocial $\mathrm{CEO}$ on a wide range of stakeholders, including company employees, customers, shareholders, and the society. We find that prosocial CEOs are associated with more stable top management teams, more satisfied customers, and more socially responsible firm decisions. We also document that prosocial CEOs improve firm value, both directly and indirectly through changing corporate policies. 


\section{References}

Achor, S. 2011. The Happiness Advantage. New York: Random House.

Agle, B., Mitchell, R., and Sonnenfeld, J. 1999. Who matters to CEOs? An investigation of stakeholder attributes and salience, corporate performance, and CEO values. Academy of Management Journal 42(5), 507-525.

Akerlof, G. 1980. A theory of social custom, of which unemployment may be one consequence. Quarterly Journal of Economics 94(4), 749-775.

Andreoni, J. 1989. Giving with impure altruism: Applications to charity and Ricardian equivalence. Journal of Political Economy 97(6), 1447-1458.

Andreoni, J. 1990. Impure altruism and donations to public goods: A theory of warm-glow giving. The Economic Journal 100(401), 464-477.

Anik, L., Aknin, L. B., Norton, M. I., and Dunn, E. W. 2009. Feeling good about giving: The benefits (and costs) of self-interested charitable behavior. In Experimental Approaches to the Study of Charity, ed. D.M. Oppenheimer and C.Y. Oliveria, 3-13. New York: Taylor and Francis Group.

Avolio, B., Waldman, D., and Mcdaniel, M. 1990. Age and work performance in nonmanagerial jobs: The effects of experience and occupational type. Academy of Management Journal 33(2), 407-422.

Batson, C. D., and Powell, A. A. 2003. Altruism and prosocial behavior. In T. Millon \& M. J. Lerner (Eds.), Handbook of Psychology, Vol. 5, pp. 463-484. John Wiley \& Sons, Inc

Becker, G. S. 1976. Altruism, egoism, and genetic fitness: Economics and sociobiology. Journal of Economic Literature 14(3), 817-826.

Bénabou, R., and Tirole, J. 2006. Incentives and prosocial behavior. American Economic Review 96(5), 1652-1678.

Bertrand, M., and Schoar, A. 2003. Managing with style: The effect of managers on firm policies. Quarterly Journal of Economics 118(4), 1169-1208.

Blau, P. M. 1964. Exchange and power in social life. New York: Wiley.

Campbell, J. 2007. Why would corporations behave in socially responsible ways? An institutional theory of corporate social responsibility. Academy of Management Review 32(3), 946-967.

Carlo, G., Eisenberg, N., Troyer, D., Switzer, G., and Speer, A. L. 1991. The altruistic personality: In what contexts is it apparent? Journal of Personality and Social Psychology 61, 450-458.

Carpenter, J., and Myers, C. 2010. Why volunteer? Evidence on the role of altruism, image, and incentives. Journal of Public Economics 94(11-12), 911-920.

Cheng, Q., Lee, J., and Shevlin, T. 2016. Internal governance and real earnings management. The Accounting Review 91(4), 1051-1085.

Cornelli, F., Kominek, Z., and Ljungqvist, A. 2013. Monitoring managers: Does it matter? Journal of Finance 68(2), 431-481.

Cronqvist, H., and Yu, F. 2017. Shaped by their daughters: Executives, female socialization, and corporate social responsibility. Journal of Financial Economics 126(3), 543-562. 
De Cremer, D. and Van Knippenberg, D. 2004. Leader self-sacrifice and leadership effectiveness: The moderating role of leader self-confidence. Organizational Behavior and Human Decision Processes 95, 140-155.

Dhaliwal, D. S., Li, O. Z., Tsang, A., and Yang, Y. G. 2011. Voluntary nonfinancial disclosure and the cost of equity capital: The initiation of corporate social responsibility reporting. The Accounting Review 86(1), 59-100.

Dunn, E., Aknin, L., and Norton, M. 2008. Spending money on others promotes happiness. Science 319(5870), 1687-1688.

Edmans, A. 2011. Does the stock market fully value intangibles? Employee satisfaction and equity prices. Journal of Financial Economics 101(3), 621-640.

Ellingsen, T., and Johannesson, M. 2007. Paying Respect. Journal of Economic Perspectives 21(4), 135-150.

Engelberg, J., Gao, P., and Parsons, C. A. 2013. The price of a CEO's rolodex. Review of Financial Studies 26(1), 79-114.

Eisenberg, N., Guthrie, I. K., Cumberland, A., Murphy, B. C., Shepard, S. A., Zhou, Q., and Carlo, G. 2002. Prosocial development in early adulthood: A longitudinal study. Journal of Personality and Social Psychology 82(6), 993-1006.

Flynn, F. J. 2003. How much should I give and how often? The effects of generosity and frequency of favor exchange on social status and productivity. Academy of Management Journal 46(5), 539-553.

Goode, W. J. 1960. A theory of role strain. American Sociology Review 25, 483-496

Guo, L., and Masulis, R. 2015. Board structure and monitoring: New evidence from CEO turnovers. Review of Financial Studies 28(10), 2770-2811.

Hambrick, D.C. 2007. Upper echelons theory: An update. Academy of Management Review 32(2), 334-343.

Harlow, R. E., and Cantor, N. 1996. Still participating after all these years: A study of life task participation in later life. Journal of Personality and Social Psychology 71(6), 1235-1249.

Hayes, R., Oyer, P. and Schaefer, S. 2006. Coworker complementarity and the stability of topmanagement teams. The Journal of Law, Economics, and Organization 22(1), 184-212.

Haynes, K., Josefy, M., and Hitt, M. 2015. Tipping point: Managers' self-interest, greed, and altruism. Journal of Leadership and Organizational Studies 22(3), 265-279.

Jensen, M., and Meckling, W. 1976. Theory of the firm: Managerial behavior, agency costs and ownership structure. Journal of Financial Economics 3(4), 305-360.

Jiao, Y. 2010. Stakeholder welfare and firm value. Journal of Banking and Finance 34(10), 25492561.

Judd, J., Olsen, K., and Stekelberg, J. 2017. How do auditors respond to CEO narcissism? Evidence from external audit fees. Accounting Horizons 31(4), 33 - 52.

Kachaner, N., Stalk, G., and Bloch., A. 2012. What you can learn from family business. Harvard Business Review 90(11), 102. 
Katz, E., and Rosenberg, J. 2005. An economic interpretation of institutional volunteering. European Journal of Political Economy 21(2), 429-443.

Lim, L., Tuli, K., and Grewal, R. 2020. Customer satisfaction and its impact on the future costs of selling. Journal of Marketing 84(4), 23-44.

Luo, X., Kanuri, V. K., and Andrews, M. 2014. How does CEO tenure matter? The mediating role of firm-employee and firm-customer relationships. Strategic Management Journal 35(4), $492-511$.

Luo, X., Wieseke, J., and Homburg, C. 2011. Incentivizing CEOs to build customer- and employee-firm relations for higher customer satisfaction and firm value. Journal of the Academy of Marketing Science 40(6), 745-758.

Lys, T., Naughton, J., and Wang, C. 2015. Signaling through corporate accountability reporting. Journal of Accounting and Economics 60(1), 56-72.

Lyubomirsky, S., Tkach, C., and Sheldon, K. M. 2004. Pursuing sustained happiness through random acts of kindness and counting one's blessings: Tests of two six-week interventions. Unpublished working paper. University of California, Riverside.

Marks, S. 1977. Multiple roles and role strain: Some notes on human energy, time and commitment. American Sociological Review, 42(6), 921-936.

Meier, S. 2007. A survey on economic theories and field evidence on pro-social behavior. In Economics and Psychology: A Promising New Cross-Disciplinary Field, ed. Bruno S. Frey and Alois Stutzer, 51-88. Cambridge: MIT Press.

Meier, S., and Stutzer, A. 2008. Is volunteering rewarding in itself? Economica 75(297), 39-59.

McWilliams, A., and Siegel, D. 2000. Corporate social responsibility and financial performance: Correlation or misspecification? Strategic Management Journal 21(5), 603-609.

Mellor, D., Hayashi, Y., Firth, L., Stokes, M., Chambers, S., and Cummins, R. 2008. Volunteering and well-being: Do self-esteem, optimism, and perceived control mediate the relationship? Journal of Social Service Research 34(4), 61-70.

Musick, M., and Wilson, J. 2003. Volunteering and depression: The role of psychological and social resources in different age groups. Social Science and Medicine 56(2), 259-269.

Olsen, K. and Stekelberg, J. 2016. CEO narcissism and corporate tax sheltering. Journal of the American Taxation Association 38 (1), 1-22.

Orlitzky, M., and Benjamin, J. D. 2001. Corporate social performance and firm risk: A metaanalytic review. Business and Society 40(4), 369-396.

Penner, L. A., Dovidio, J. F, Piliavin, J. A., and Schroeder, D. A. 2005. Prosocial behavior: Multilevel perspectives. Annual Review of Psychology 56(1), 365-392.

Piliavin, J. A., and Charng, H. W. 1990. Altruism: A review of recent theory and research. Annual Review of Sociology 16, 27-65

Rodell, J. 2013. Finding meaning through volunteering: why do employees volunteer and what does it mean for their jobs? Academy of Management Journal 56(5), 1274-1294.

Rodell, J. B., Breitsohl, H., Schröder, M., and Keating, D. J. 2016. Employee volunteering. Journal of Management 42(1), 55-84. 
Rushton, J. P. 1980. Altruism, socialization and society. Englewood Cliffs, NJ: Prentice-Hall.

Schoar, A., and Zuo, L. 2017. Shaped by booms and busts: How the economy impacts CEO careers and management styles. Review of Financial Studies 30(5), 1425-1456.

Sen, A. K. 1977. Rational fools: A critique of the behavioral foundations of economic theory. Philosophy and Public Affairs 6(4), 317-344.

Sieber, S. 1974. Toward a theory of role accumulation. American Sociological Review 39(4), 567578.

Sobel, M. 1982. Asymptotic confidence intervals for indirect effects in structural equation models. Sociological Methodology 13, 290-312.

Van Knippenberg, B., and Van Knippenberg, D. 2005. Leader self-sacrifice and leadership effectiveness: The moderating role of leader prototypicality. Journal of Applied Psychology $90,25-37$.

Wally, S., and Baum, J. R. 1994. Personal and structural determinants of the pace of strategic decision making. Academy of Management Journal 37(4), 932-956.

Wieser, R. 2005. Research and development productivity and spillovers: Empirical evidence at the firm level. Journal of Economic Surveys 19(4), 587-621.

Wilson, J. 2012. Volunteerism research. Nonprofit and Voluntary Sector Quarterly 41(2), 176212.

Whitener, E. M., Brodt, S. E., Korsgaard, M. A., and Werner, J. M. 1998. Manager as initiators of trust: An exchange relationship framework for understanding managerial trustworthy behavior. Academy of Management 23(3), 513-530.

Zaccaro, S. J., Banks, D., Kiechel-Koles, L., Kemp, C., and Bader, P. 2009. Leader and team adaptation: The influences and development of key attributes and processes. Tech. Rep. No. \#1256, U.S. Army Research Institute for Behavioral and Social Sciences, Arlington, VA. 


\section{Appendix. Variable Definitions}

\begin{tabular}{|c|c|c|}
\hline Variable & Definition & Database \\
\hline Advertising & $\begin{array}{l}\text { Advertising expense scaled by average total assets for the } \\
\text { fiscal year. }\end{array}$ & Compustat \\
\hline Auditor & $\begin{array}{l}\text { An indicator variable equal to one if individual worked as an } \\
\text { auditor before, and zero otherwise. We identify individuals } \\
\text { with auditor experience if any of their prior role names } \\
\text { contain the word "auditor". }\end{array}$ & BoardEx \\
\hline Banking & $\begin{array}{l}\text { An indicator variable equal to one if individual has worked in } \\
\text { the banking industry before, and zero otherwise. We identify } \\
\text { individuals with banking experience if any of their prior roles } \\
\text { are in industries that contain the word "bank". }\end{array}$ & BoardEx \\
\hline$C A R$ & $\begin{array}{l}\text { Cumulative abnormal return over the } 12 \text { months prior to the } \\
\text { end of the fiscal year. Calculated as buy-hold stock return } \\
\text { adjusted by the CRSP value-weighted return over the same } \\
\text { period. }\end{array}$ & CRSP \\
\hline Cash & $\begin{array}{l}\text { Cash at the end of the fiscal year scaled by average total } \\
\text { assets for the fiscal year. }\end{array}$ & Compustat \\
\hline CEO_Leave & $\begin{array}{l}\text { An indicator variable equal to one if the CEO leaves the firm } \\
\text { in that fiscal year, and zero otherwise. }\end{array}$ & $\begin{array}{l}\text { BoardEx, } \\
\text { Execucomp }\end{array}$ \\
\hline CEOAge & CEO’s age. & BoardEx \\
\hline CEOTenure & $\begin{array}{l}\text { Number of years the CEO has been the CEO of the firm at } \\
\text { the end of the fiscal year. }\end{array}$ & BoardEx \\
\hline CFO & $\begin{array}{l}\text { Cash flow from operations scaled by average total assets for } \\
\text { the fiscal year. }\end{array}$ & Compustat \\
\hline Charity & $\begin{array}{l}\text { An indicator variable equal to one if the CEO has been } \\
\text { involved with any charities, and zero otherwise. Charities are } \\
\text { organizations defined as "Charitable Organizations" by the } \\
\text { IRS. }\end{array}$ & $\begin{array}{l}\text { Combination } \\
\text { of IRS and } \\
\text { BoardEx }\end{array}$ \\
\hline CharityImprove & $\begin{array}{l}\text { An indicator variable. For a given CEO turnover event, if a } \\
\text { charitable CEO replaces a non-charitable CEO, this variable } \\
\text { equals one for all the years when both CEOs are in position. } \\
\text { For the other types of CEO turnovers, this variable equals } \\
\text { zero for all the years when both CEOs are in position. }\end{array}$ & $\begin{array}{l}\text { Combination } \\
\text { of IRS and } \\
\text { BoardEx }\end{array}$ \\
\hline Consultant & $\begin{array}{l}\text { An indicator variable equal to one if individual has worked } \\
\text { as a management consultant before, and zero otherwise. We } \\
\text { identify individuals with consultant experience if any of their } \\
\text { prior role names contain the word "consultant". }\end{array}$ & BoardEx \\
\hline$C P A$ & $\begin{array}{l}\text { An indicator variable equal to one if individual has a CPA, } \\
\text { and zero otherwise. We identify individuals with a CPA if } \\
\text { any of their qualifications contain "cpa", "chartered public } \\
\text { accountant", "chartered accountant", "certified public } \\
\text { acocuntant", or "certified accountant". }\end{array}$ & BoardEx \\
\hline Cust_Satis & $\begin{array}{l}\text { Most recent annual customer satisfaction score before the } \\
\text { end of the firm's fiscal year, as measured by the American } \\
\text { Customer Satisfaction Index. }\end{array}$ & ACSI \\
\hline
\end{tabular}




\begin{tabular}{|c|c|c|}
\hline Employee_KLD & $\begin{array}{l}\text { Net score of KLD ratings on the firm's employee relations } \\
\text { performance, measured as total strengths minus total } \\
\text { concerns in the KLD employee relations category. }\end{array}$ & $\begin{array}{l}\text { MSCI ESG } \\
\text { KLD STATS }\end{array}$ \\
\hline FirmAge & $\begin{array}{l}\text { Age of the firm calculated using the Field-Ritter dataset of } \\
\text { founding dates. }\end{array}$ & $\begin{array}{l}\text { Field-Ritter } \\
\text { dataset }\end{array}$ \\
\hline Grad_Law & $\begin{array}{l}\text { An indicator variable equal to one if individual has a juris } \\
\text { doctorate degree, and zero otherwise. We identify individuals } \\
\text { with a juris doctorate if any of their qualifications contain } \\
\text { "jd" or "juris doctor". }\end{array}$ & BoardEx \\
\hline Instown_Perc & $\begin{array}{l}\text { Percentage of shares in the firm held by institutional } \\
\text { shareholders at the end of fiscal year. }\end{array}$ & $\begin{array}{l}\text { Thomson } \\
\text { Reuters 13F }\end{array}$ \\
\hline InternalCEO & $\begin{array}{l}\text { An indicator variable equal to one if the CEO was promoted } \\
\text { internally, and zero otherwise. }\end{array}$ & BoardEx \\
\hline Investment & $\begin{array}{l}\text { An indicator variable equal to one if the individual worked in } \\
\text { investment firms before, and zero otherwise. We define } \\
\text { investment firms as firms classified by BoardEx as } \\
\text { "investment companies," "private equity," or "speciality and } \\
\text { other finance". }\end{array}$ & BoardEx \\
\hline Legal & $\begin{array}{l}\text { An indicator variable equal to one if the individual has } \\
\text { worked in the legal industry before, and zero otherwise. We } \\
\text { identify individuals with legal experience if any of their prior } \\
\text { roles are in industries that contain the word "legal" or "law". }\end{array}$ & BoardEx \\
\hline Leverage & $\begin{array}{l}\text { Total liabilities divided by total assets at the end of fiscal } \\
\text { year. }\end{array}$ & Compustat \\
\hline $\log _{-} A T$ & Natural logarithm of total assets at the end of fiscal year. & Compustat \\
\hline Log_Network & $\begin{array}{l}\text { Natural logarithm of }(1+\text { Network }) \text {. Network is an individual's } \\
\text { total number of social connections via education, working } \\
\text { experience, and other activities as listed in the BoardEx } \\
\text { network files before her first becoming a CEO. }\end{array}$ & BoardEx \\
\hline$M B A$ & $\begin{array}{l}\text { An indicator variable equal to one if individual has an MBA, } \\
\text { and zero otherwise. We identify individuals with an MBA if } \\
\text { any of their qualifications contain "mba" or "masters of } \\
\text { business admin". }\end{array}$ & BoardEx \\
\hline$M T B$ & $\begin{array}{l}\text { The ratio of market value of equity to book value of equity at } \\
\text { the end of the fiscal year. }\end{array}$ & Compustat \\
\hline NonCharity & $\begin{array}{l}\text { An indicator variable equal to one if the CEO is involved in } \\
\text { any non-charities, and zero otherwise. Non-charities are } \\
\text { organizations that are not defined as "Charitable } \\
\text { Organizations" by the IRS. }\end{array}$ & $\begin{array}{l}\text { Combination } \\
\text { of IRS and } \\
\text { BoardEx }\end{array}$ \\
\hline Num_Analysts & $\begin{array}{l}\text { Number of analysts following the firm based on the most } \\
\text { recent consensus estimate at the end of the fiscal year. }\end{array}$ & IBES \\
\hline Post & $\begin{array}{l}\text { An indicator variable equal to one if the year is after a CEO } \\
\text { turnover, and zero otherwise. }\end{array}$ & \\
\hline PriorJobs & $\begin{array}{l}\text { The principal component of PriorFirms, PriorIndustries, and } \\
\text { PriorPositions. }\end{array}$ & BoardEx \\
\hline
\end{tabular}




\begin{tabular}{|c|c|c|}
\hline PriorIndustry & $\begin{array}{l}\text { Number of other firms in which the individual was employed } \\
\text { before her first becoming a CEO. }\end{array}$ & BoardEx \\
\hline PriorFirms & $\begin{array}{l}\text { Number of other industries the individual worked in before } \\
\text { her first becoming a CEO. }\end{array}$ & BoardEx \\
\hline PriorPositions & $\begin{array}{l}\text { Number of positions the individual held before her first } \\
\text { becoming a CEO. }\end{array}$ & BoardEx \\
\hline$R D$ & $\begin{array}{l}\text { R\&D expenditure divided by average total assets for the } \\
\text { fiscal year. }\end{array}$ & Compustat \\
\hline ReturnVolatility & $\begin{array}{l}\text { Standard deviation of raw daily returns for the firm adjusted } \\
\text { for CRSP value-weighted returns in the } 12 \text { months prior to } \\
\text { the end of the fiscal year. }\end{array}$ & CRSP \\
\hline$R O A$ & $\begin{array}{l}\text { Income before extraordinary items divided by average total } \\
\text { assets for the fiscal year. }\end{array}$ & Compustat \\
\hline RevenueGrowth & $\begin{array}{l}\text { Annual change in total revenue divided by total revenue in } \\
\text { the previous year. }\end{array}$ & Compustat \\
\hline SizeAdjRet & $\begin{array}{l}\text { Raw stock returns for the firm calculated over the } 12 \text { months } \\
\text { prior to the end of the fiscal year, adjusted for the average } \\
\text { return of all firms in the same size decile. Size deciles are } \\
\text { formed at the end of each fiscal year. }\end{array}$ & $\begin{array}{l}\text { CRSP, } \\
\text { Compustat }\end{array}$ \\
\hline Subor_PercShrsOwn & Percentage of the firm's shares owned by the subordinate. & Execucomp \\
\hline SubordinateAge & Subordinate's age. & BoardEx \\
\hline SubordinateTenure & $\begin{array}{l}\text { Number of years the subordinate has been employed by the } \\
\text { current firm. }\end{array}$ & BoardEx \\
\hline TimeToCEO & $\begin{array}{l}\text { Number of years between the start of an individual's career } \\
\text { and her first becoming a CEO. The start of an individual's } \\
\text { career is defined as the year in which she was } 24 \text { years of } \\
\text { age. }\end{array}$ & BoardEx \\
\hline TimeToTMT & $\begin{array}{l}\text { Number of years between the start of an individual's career } \\
\text { and her first becoming a top executive. The start of an } \\
\text { individual's career is defined as the year in which she was } 24 \\
\text { years of age. }\end{array}$ & BoardEx \\
\hline Tobins $Q$ & $\begin{array}{l}\text { The market value of assets (measured as total assets plus } \\
\text { total market capitalization, minus total common equity, } \\
\text { minus deferred taxes on the balance sheet), divided by the } \\
\text { book value of assets at the end of the fiscal year. }\end{array}$ & Compustat \\
\hline Total_KLD & $\begin{array}{l}\text { Net score of corporate social performance of the firm, } \\
\text { measured as total strengths minus total concerns in five } \\
\text { social rating categories of KLD ratings data: corporate } \\
\text { governance, community, diversity, employee relations, } \\
\text { environment, and product. }\end{array}$ & $\begin{array}{l}\text { MSCI ESG } \\
\text { KLD STATS }\end{array}$ \\
\hline Turnover & $\begin{array}{l}\text { An indicator variable equal to one if the subordinate leaves } \\
\text { the firm in that fiscal year, and zero otherwise. }\end{array}$ & BoardEx \\
\hline Woman & $\begin{array}{l}\text { An indicator variable equal to one if the individual is a } \\
\text { woman, and zero otherwise. }\end{array}$ & BoardEx \\
\hline
\end{tabular}




\section{Table 1. Descriptive Statistics}

This table presents descriptive statistics for the sample used in testing H1. The sample includes 41,205 individuals who first became CEOs from 1950 to 2019. Among these executives, 3,548 also became CEOs of public firms during the sample period. Panel A reports the mean and median of all variables for these individuals and public firms. Panel B presents the Pearson (above the diagonal) and Spearman (below the diagonal) correlations among all the variables. Correlations significant at the $10 \%$ level are marked in bold. Definitions of all variables are reported in Appendix.

Panel A: Individual descriptive statistics

\begin{tabular}{lcccccc}
\hline Variable & $\mathrm{N}$ & Mean & Std Dev & P25 & Median & P75 \\
\hline Charity & 41,205 & 0.282 & 0.450 & 0.000 & 0.000 & 1.000 \\
NonCharity & 41,205 & 0.561 & 0.496 & 0.000 & 1.000 & 1.000 \\
TimeToCEO (Any firm) & 41,205 & 22.160 & 9.351 & 16.000 & 22.000 & 29.000 \\
TimeToCEO (Public Firm) & 3,548 & 26.285 & 7.295 & 21.000 & 26.000 & 31.000 \\
Woman & 41,205 & 0.055 & 0.228 & 0.000 & 0.000 & 0.000 \\
MBA & 41,205 & 0.260 & 0.439 & 0.000 & 0.000 & 1.000 \\
Grad_Law & 41,205 & 0.057 & 0.232 & 0.000 & 0.000 & 0.000 \\
CPA & 41,205 & 0.065 & 0.247 & 0.000 & 0.000 & 0.000 \\
Auditor & 41,205 & 0.018 & 0.132 & 0.000 & 0.000 & 0.000 \\
Consultant & 41,205 & 0.126 & 0.331 & 0.000 & 0.000 & 0.000 \\
Banking & 41,205 & 0.114 & 0.317 & 0.000 & 0.000 & 0.000 \\
Legal & 41,205 & 0.021 & 0.144 & 0.000 & 0.000 & 0.000 \\
Investment & 41,205 & 0.141 & 0.348 & 0.000 & 0.000 & 0.000 \\
PriorJobs & 41,205 & -0.067 & 0.851 & -0.731 & -0.218 & 0.218 \\
$\quad$ PriorIndustry & 41,205 & 1.903 & 0.854 & 1.000 & 2.000 & 2.000 \\
$\quad$ PriorFirms & 41,205 & 4.652 & 3.536 & 2.000 & 4.000 & 6.000 \\
$\quad$ PriorPositions & 41,205 & 5.090 & 2.765 & 3.000 & 5.000 & 6.000 \\
Log_Network & 41,205 & 5.364 & 1.694 & 4.290 & 5.638 & 6.639 \\
Log_AT & 3,548 & 6.133 & 2.251 & 4.486 & 6.139 & 7.705 \\
MTB & 3,548 & 3.121 & 5.847 & 1.111 & 1.975 & 3.666 \\
Leverage & 3,548 & 0.583 & 2.482 & 0.000 & 0.202 & 0.722 \\
\hline
\end{tabular}


Table 1. Descriptive Statistics (Cont.)

Panel B: Pearson and Spearman correlation matrix

\begin{tabular}{|c|c|c|c|c|c|c|c|c|c|c|c|c|c|c|c|c|c|c|}
\hline Variable & [1] & [2] & [3] & [4] & [5] & [6] & [7] & [8] & [9] & [10] & [11] & [12] & [13] & [14] & [15] & [16] & [17] & [18] \\
\hline $\begin{array}{l}\text { [1] TimeToCEO } \\
\text { (Any firm) }\end{array}$ & & 0.769 & 0.022 & 0.037 & 0.009 & -0.042 & -0.004 & 0.028 & -0.008 & -0.005 & 0.003 & -0.013 & -0.093 & 0.247 & $-\mathbf{- 0 . 0 5 0}$ & 0.129 & -0.017 & 0.064 \\
\hline $\begin{array}{l}\text { [2] TimeToCEO } \\
\text { (Public firm) }\end{array}$ & 0.758 & & 0.061 & 0.067 & -0.011 & -0.038 & -0.023 & -0.006 & -0.029 & 0.032 & 0.022 & -0.031 & -0.058 & 0.066 & -0.139 & 0.086 & -0.047 & 0.043 \\
\hline [3] Charity & 0.016 & 0.061 & & 0.372 & 0.088 & 0.040 & 0.056 & -0.023 & -0.018 & -0.033 & 0.093 & 0.032 & 0.085 & 0.149 & 0.137 & 0.232 & 0.038 & 0.085 \\
\hline [4] NonCharity & 0.031 & 0.065 & 0.372 & & 0.061 & 0.033 & 0.071 & -0.004 & 0.016 & -0.024 & 0.094 & 0.045 & 0.103 & 0.157 & 0.128 & 0.297 & 0.029 & 0.119 \\
\hline [5] Woman & 0.010 & -0.015 & 0.088 & 0.061 & & -0.004 & 0.013 & -0.002 & 0.014 & 0.004 & 0.029 & 0.015 & -0.006 & 0.078 & 0.041 & 0.011 & -0.010 & -0.022 \\
\hline [6] $M B A$ & -0.036 & -0.037 & 0.040 & 0.033 & -0.004 & & -0.114 & -0.019 & -0.002 & 0.032 & 0.036 & -0.079 & 0.050 & 0.097 & 0.260 & 0.065 & 0.025 & 0.049 \\
\hline [7] Grad_Law & -0.002 & -0.022 & 0.056 & 0.071 & 0.013 & -0.114 & & -0.034 & -0.038 & -0.017 & 0.004 & 0.534 & 0.032 & 0.079 & 0.079 & 0.030 & -0.005 & 0.002 \\
\hline [8] CPA & 0.029 & -0.009 & -0.023 & -0.004 & -0.002 & -0.019 & -0.034 & & 0.313 & 0.022 & 0.007 & -0.020 & -0.013 & -0.053 & -0.061 & 0.000 & -0.023 & 0.027 \\
\hline [9] Auditor & -0.006 & -0.027 & -0.018 & 0.016 & 0.014 & -0.002 & -0.038 & 0.313 & & 0.015 & 0.000 & -0.021 & 0.013 & 0.014 & -0.006 & 0.021 & -0.012 & 0.014 \\
\hline [10] Consultant & -0.001 & 0.036 & -0.033 & -0.024 & 0.004 & 0.032 & -0.017 & 0.022 & 0.015 & & -0.016 & -0.006 & 0.004 & 0.045 & 0.038 & -0.111 & 0.008 & -0.055 \\
\hline [11] Banking & -0.002 & 0.018 & 0.093 & 0.094 & 0.029 & 0.036 & 0.004 & 0.007 & 0.000 & -0.016 & & 0.005 & 0.127 & 0.082 & 0.063 & 0.134 & -0.041 & 0.076 \\
\hline [12] Legal & -0.009 & -0.029 & 0.032 & 0.045 & 0.015 & -0.079 & 0.534 & -0.020 & -0.021 & -0.006 & 0.005 & & 0.017 & 0.084 & 0.068 & 0.018 & 0.000 & 0.001 \\
\hline [13] Investment & -0.089 & -0.054 & 0.085 & 0.103 & -0.006 & 0.050 & 0.032 & -0.013 & 0.013 & 0.004 & 0.127 & 0.017 & & 0.132 & 0.150 & 0.159 & -0.034 & 0.073 \\
\hline [14] PriorJobs & 0.262 & 0.088 & 0.159 & 0.159 & 0.083 & 0.098 & 0.086 & -0.053 & 0.008 & 0.047 & 0.088 & 0.093 & 0.150 & & 0.416 & 0.192 & 0.033 & 0.054 \\
\hline [15] Log_Network & -0.026 & $-\mathbf{0 . 1 3 0}$ & 0.146 & 0.143 & 0.043 & 0.250 & 0.086 & -0.045 & 0.003 & 0.034 & 0.062 & 0.067 & 0.147 & 0.408 & & 0.170 & 0.074 & 0.021 \\
\hline [16] Log_AT & 0.116 & 0.082 & 0.242 & 0.296 & 0.013 & 0.067 & 0.030 & -0.002 & 0.020 & -0.108 & 0.146 & 0.020 & 0.161 & 0.195 & 0.198 & & $-\mathbf{- 0 . 0 3 3}$ & 0.452 \\
\hline [17] MTB & -0.023 & -0.031 & 0.004 & 0.005 & -0.011 & 0.001 & -0.004 & -0.005 & -0.006 & 0.012 & -0.027 & 0.000 & -0.011 & 0.003 & 0.021 & -0.085 & & 0.161 \\
\hline [18] Leverage & 0.011 & -0.001 & 0.000 & 0.025 & -0.019 & 0.020 & -0.009 & 0.016 & 0.016 & -0.004 & 0.067 & 0.003 & 0.061 & 0.025 & 0.008 & 0.147 & 0.425 & \\
\hline
\end{tabular}




\section{Table 2. Regression Results of Time Taken to be Promoted to CEO}

This table presents results from OLS regressions of the time taken to be promoted to a CEO on charity involvement. The sample consists of 41,205 individuals who became CEOs and 3,548 individuals who became CEOs of public firms from 1950 to 2019. Charity is an indicator variable equal to one if the individual is involved in charitable organizations, and zero otherwise. The definitions of all other variables are reported in the Appendix. $t$-statistics are reported in brackets. Industry and career start year fixed effects are included. Significance at the $10 \%, 5 \%$, and $1 \%$ level are denoted $*, * *$, and $* * *$, respectively.

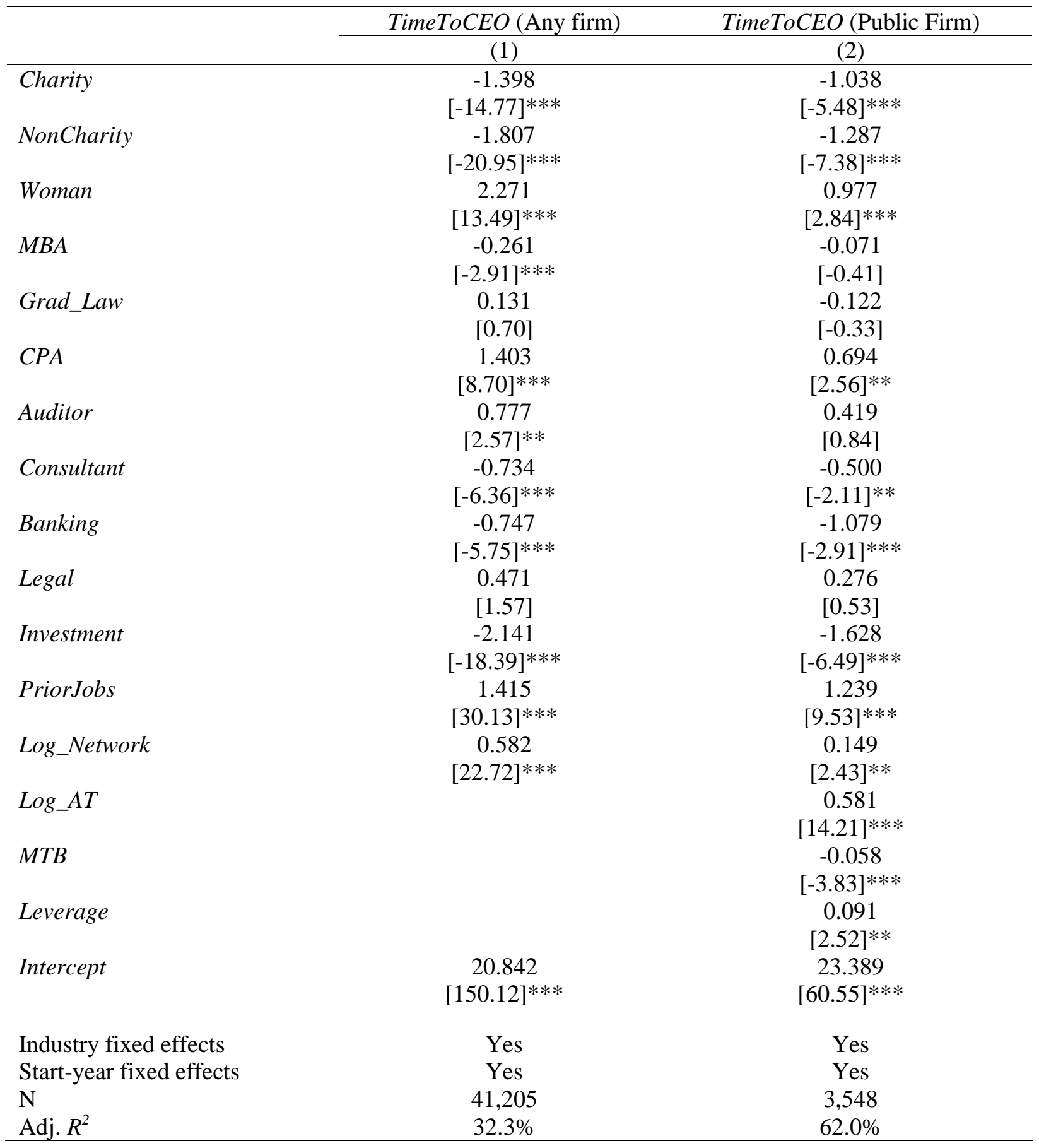




\section{Table 3. Executive Subordinate Turnover Analysis}

This table presents results for analyses of $\mathrm{H} 2$. The sample includes 108,464 subordinate-firm-year observations across 2,570 firms and 32,844 firm-years for the period of 1992-2018. Panel A presents descriptive statistics for all the variables at the subordinate-firm-year level. Panel B presents results from OLS regressions of executive subordinate turnover on CEO charity involvement. The main dependent variable, Turnover, equals one if the subordinate leaves the firm in year $\mathrm{t}+1$, and zero otherwise. The main independent variable, Charity, equals one if the CEO of the firm in year $t$ is involved in charitable organizations, and zero otherwise. The definitions of all other independent variables are reported in Appendix. In Panel B, Column (1) - (3) reports regression results using all subordinates, subordinates younger than 50 years old, and subordinates older than 49 years old, respectively. In Column (4), the sample includes only subordinates younger than 50 years old in the firm-years before and after a CEO turnover. Standard errors are clustered at the firm level, and $t$-statistics are reported in the brackets. Industry fixed effects are included. This panel also reports Wald chi-square tests on the difference between coefficients on Charity in Column (2) and (3). Significance at the $10 \%, 5 \%$, and $1 \%$ level is denoted $* * *$, and $* * *$, respectively.

Panel A: Descriptive statistics for subordinate turnover analysis

\begin{tabular}{lccccc}
\hline Variable & Mean & Std Dev & P25 & Median & P75 \\
\hline Turnover & 0.175 & 0.380 & 0.000 & 0.000 & 0.000 \\
Charity & 0.536 & 0.499 & 0.000 & 1.000 & 1.000 \\
NonCharity & 0.789 & 0.408 & 1.000 & 1.000 & 1.000 \\
Log_AT & 7.464 & 1.669 & 6.250 & 7.333 & 8.556 \\
MTB & 3.417 & 3.550 & 1.567 & 2.379 & 3.844 \\
Leverage & 0.516 & 0.208 & 0.365 & 0.525 & 0.666 \\
ROA & 0.048 & 0.092 & 0.019 & 0.052 & 0.092 \\
SizeAdjRet & 0.095 & 0.491 & -0.183 & 0.022 & 0.257 \\
CEOAge & 56.101 & 7.338 & 51.000 & 56.000 & 61.000 \\
CEOTenure & 8.077 & 7.274 & 3.000 & 6.000 & 11.000 \\
InternalCEO & 0.639 & 0.480 & 0.000 & 1.000 & 1.000 \\
CEO_Leave & 0.122 & 0.327 & 0.000 & 0.000 & 0.000 \\
SubordinateAge & 51.506 & 6.884 & 47.000 & 51.000 & 56.000 \\
SubordinateTenure & 7.397 & 9.136 & 0.000 & 4.000 & 12.000 \\
Subor_PercShrsOwn & 0.106 & 0.214 & 0.001 & 0.018 & 0.098 \\
N & & & 108,464 & & \\
\hline
\end{tabular}


Table 3. Executive Subordinate Turnover Analysis (Cont.)

Panel B: Regression results of subordinate turnover

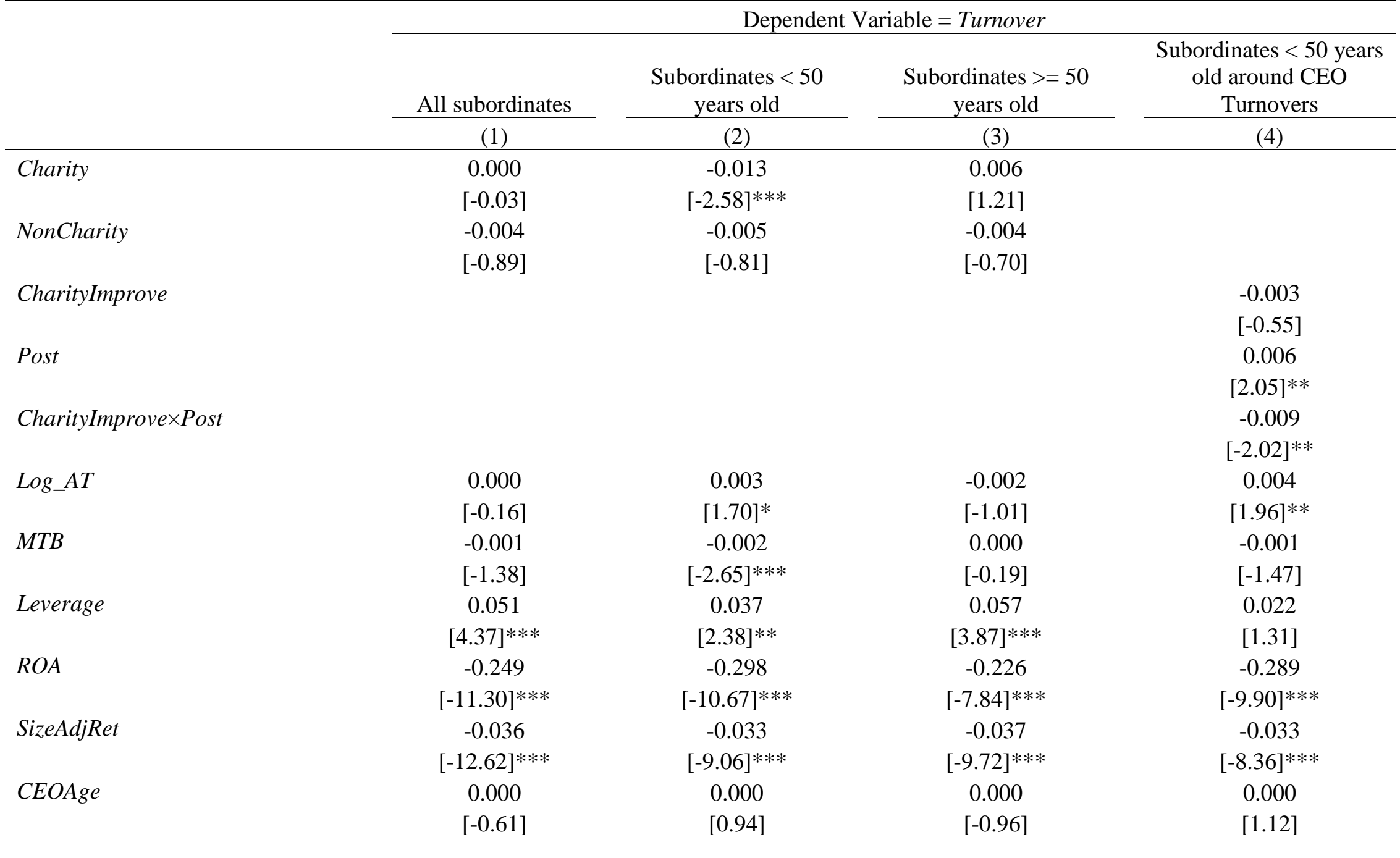




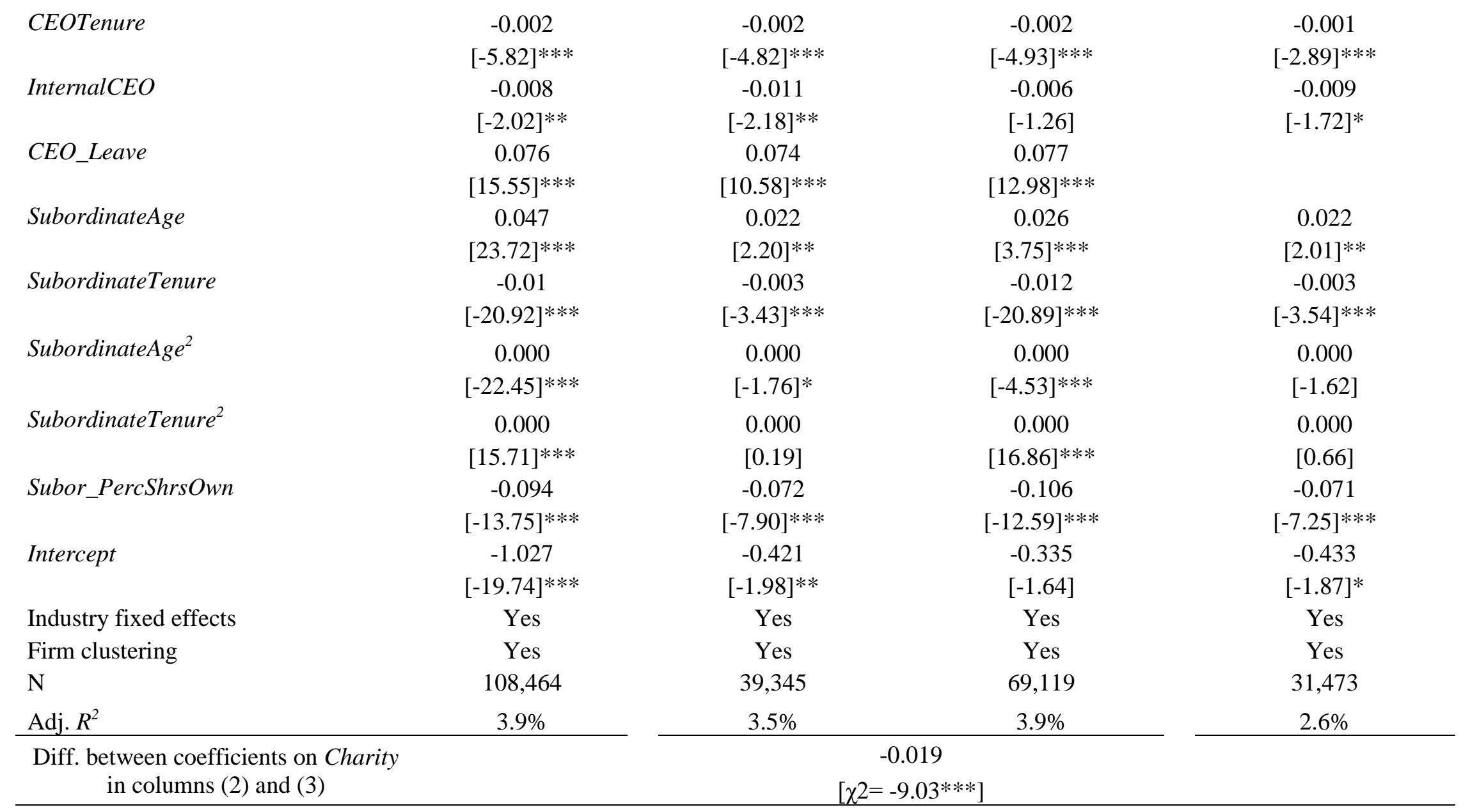




\section{Table 4. Regression Results of Corporate Employee Policies}

This table presents results from OLS regressions of firms' CSR scores on the employee category on CEO charity involvement. The sample includes 20,597 firm-years for the period of 1992-2016. Employee_KLD is the KLD rating on the firm's employee relations category. Charity equals one if the CEO of the firm is involved in charitable organizations, and zero otherwise. The definitions of all other independent variables are reported in Appendix. In Column (2), the sample consists of 15,687 firm-years around CEO turnovers. Standard errors are clustered at the firm level, and $t$-statistics are reported in the brackets. Year and industry fixed effects are both included. Significance at the $10 \%, 5 \%$, and $1 \%$ level is denoted $* * *$, and $* * *$, respectively.

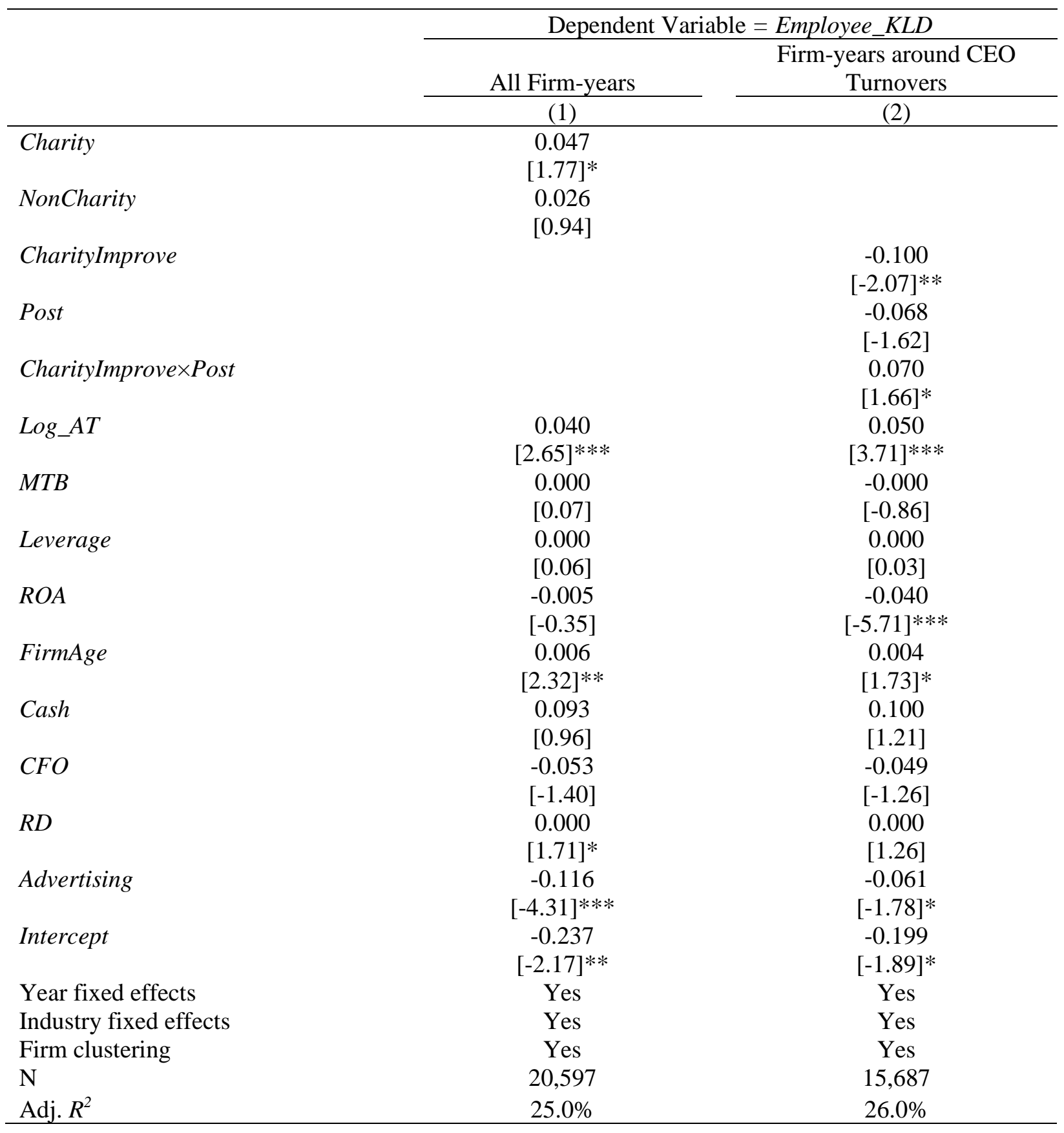




\section{Table 5. Regression Results of Firm Customer Satisfaction}

This table presents results from OLS regressions of firms' ACSI customer satisfaction scores on CEO charity involvement. The sample includes 1,224 firm-years for the period of 1995-2018. Charity equals one if the CEO of the firm is involved with charitable organizations, and zero otherwise. The definitions of all other independent variables are reported in Appendix. In Column (2), the sample consists of 742 firm-years around CEO turnovers. Standard errors are clustered at the firm level, and $t$-statistics are reported in the brackets. Year and industry fixed effects are both included. Significance at the $10 \%, 5 \%$, and $1 \%$ level is denoted $* * *$, and $* * *$, respectively.

Dependent Variable $=$ Cust_Satis

\begin{tabular}{|c|c|c|}
\hline & \multicolumn{2}{|c|}{ Dependent Variable $=$ Cust_Satis } \\
\hline & All Firm-years & $\begin{array}{c}\text { Firm-years around CEO } \\
\text { Turnovers }\end{array}$ \\
\hline & $(1)$ & $(2)$ \\
\hline \multirow[t]{2}{*}{ Charity } & 0.583 & \\
\hline & {$[1.88]^{*}$} & \\
\hline \multirow[t]{2}{*}{ NonCharity } & 0.540 & \\
\hline & [0.99] & \\
\hline \multirow[t]{2}{*}{ CharityImprove } & & -1.066 \\
\hline & & {$[-2.51]^{* *}$} \\
\hline \multirow[t]{2}{*}{ Post } & & -1.315 \\
\hline & & {$[-1.48]$} \\
\hline \multirow[t]{2}{*}{ CharityImprove $\times$ Post } & & 1.458 \\
\hline & & {$[1.65]^{*}$} \\
\hline \multirow[t]{2}{*}{ CEOTenure } & -0.005 & 0.000 \\
\hline & {$[-0.25]$} & {$[-0.01]$} \\
\hline \multirow[t]{2}{*}{$L_{o g} A T$} & -0.812 & 0.109 \\
\hline & {$[-6.40]^{* * *}$} & [0.49] \\
\hline \multirow[t]{2}{*}{$M T B$} & -0.021 & -0.056 \\
\hline & {$[-0.71]$} & {$[-1.42]$} \\
\hline \multirow[t]{2}{*}{ Leverage } & 4.411 & 7.396 \\
\hline & {$[3.66]^{* * *}$} & {$[4.55]^{* * *}$} \\
\hline \multirow[t]{2}{*}{$R O A$} & 12.286 & 18.171 \\
\hline & {$[5.34]^{* * *}$} & {$[6.25]^{* * *}$} \\
\hline \multirow[t]{2}{*}{ Advertising } & 27.009 & 31.783 \\
\hline & {$[4.45]^{* * *}$} & {$[3.12]^{* * *}$} \\
\hline \multirow[t]{2}{*}{ RevenueGrowth } & 1.033 & 0.304 \\
\hline & {$[2.29]^{* *}$} & {$[0.57]$} \\
\hline \multirow[t]{2}{*}{ Intercept } & 82.377 & 68.879 \\
\hline & {$[40.81]^{* * *}$} & {$[26.41]^{* * *}$} \\
\hline Year fixed effects & Yes & Yes \\
\hline Industry fixed effects & Yes & Yes \\
\hline Firm clustering & Yes & Yes \\
\hline $\mathrm{N}$ & 1,224 & 742 \\
\hline Adj. $R^{2}$ & $57.4 \%$ & $66.5 \%$ \\
\hline
\end{tabular}




\section{Table 6. Regression Results of Firm Corporate Social Performance}

This table presents results from OLS regressions of firms' CSR performance on CEO charity involvement. The sample includes 20,597 firm-years for the period of 1992-2016. Total_KLD represents the firm's KLD rating on corporate governance, community, diversity, employee relations, environment, and product categories. Charity equals one if the CEO of the firm is involved in charitable organizations and zero otherwise. The definitions of all other independent variables are reported in Appendix. In Column (2), the sample consists only of 15,687 firm-years around CEO turnovers. Standard errors are clustered at the firm level, and $t$-statistics are reported in the brackets. Year and industry fixed effects are both included. Significance at the $10 \%, 5 \%$, and $1 \%$ level is denoted $*, * *$, and $* * *$, respectively.

\section{Dependent Variable $=$ Total_KLD}

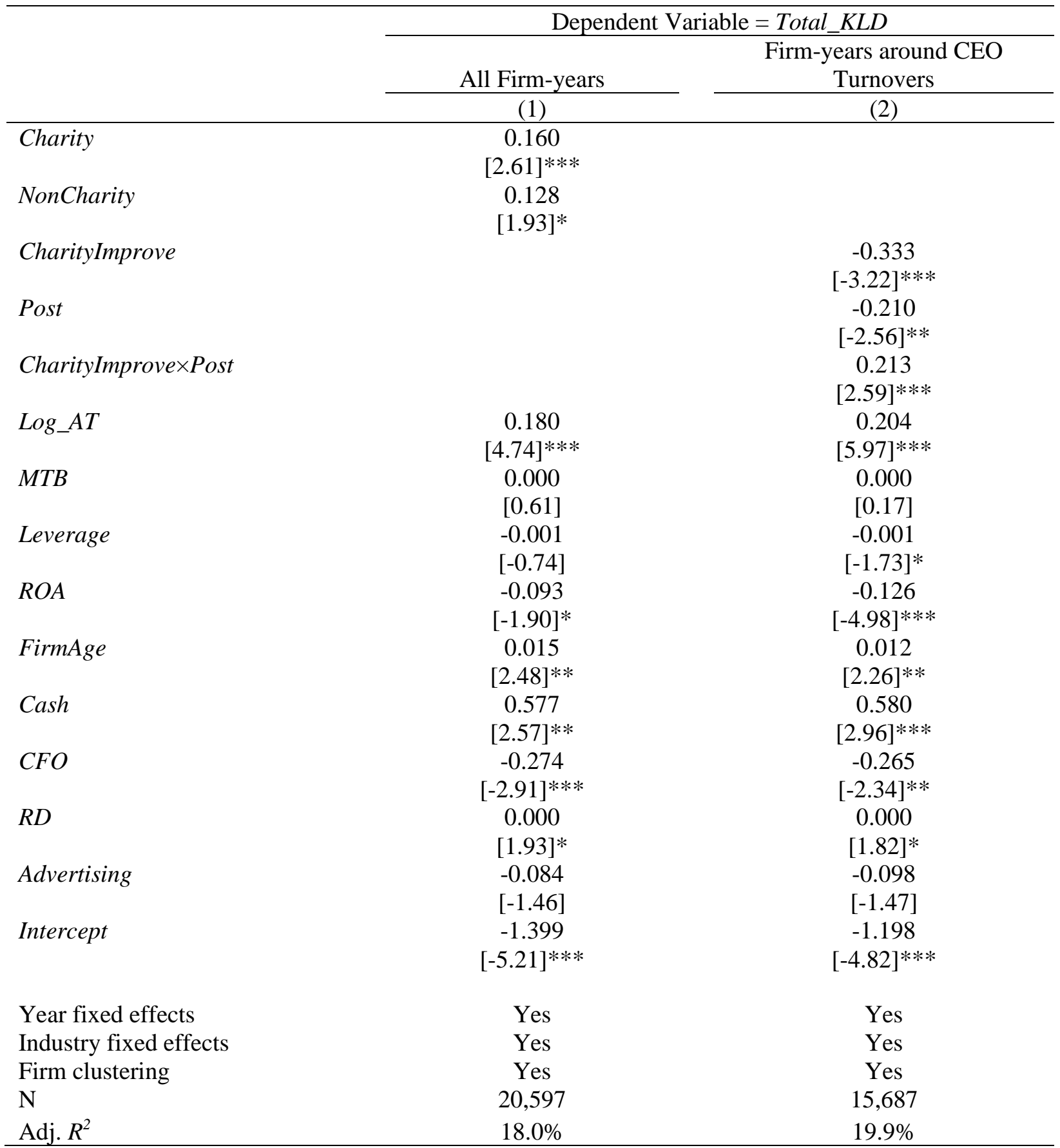




\section{Table 7. Regression Results of Firm Value}

This table presents results from OLS regressions of firm value or performance in the following year on CEO charity involvement. In Panel A, sample includes firm-years with available data for the period of 1992-2018. In Panel B, the sample consists only of firm-years before and after a CEO turnover. Tobins $Q$ and $R O A$ represent Tobin's $\mathrm{Q}$ and return on assets. SizeAdjRet is the raw stock return for the firm adjusted for the average return of all firms in the same size decile. The definitions of all other variables are reported in Appendix. Standard errors are clustered at the firm level, and $t$-statistics are reported in the brackets. Year and industry fixed effects are both included. Significance at the 10\%, $5 \%$, and $1 \%$ level are denoted $*, * *$, and $* * *$, respectively.

Panel A: Regression results using all firm-years

\begin{tabular}{|c|c|c|c|}
\hline & $\begin{array}{c}\text { Tobins } Q \\
(1)\end{array}$ & $\begin{array}{c}\text { SizeAdjRet } \\
(2)\end{array}$ & $\begin{array}{c}R O A \\
(3) \\
\end{array}$ \\
\hline \multirow[t]{2}{*}{ Charity } & 0.033 & 0.001 & 0.002 \\
\hline & {$[2.68]^{* * *}$} & {$[3.68]^{* * *}$} & {$[1.89]^{*}$} \\
\hline \multirow[t]{2}{*}{ NonCharity } & 0.004 & 0.002 & 0.002 \\
\hline & {$[0.30]$} & {$[4.30]^{* * *}$} & {$[1.35]$} \\
\hline \multirow[t]{2}{*}{$L_{o g} A T$} & -0.047 & 0.001 & -0.002 \\
\hline & {$[-8.79] * * *$} & {$[3.08] * * *$} & {$[-4.75]^{* * *}$} \\
\hline \multirow[t]{2}{*}{$M T B$} & 0.002 & 0.000 & 0.001 \\
\hline & {$[0.60]$} & {$[-0.14]$} & {$[2.87]^{* * *}$} \\
\hline \multirow[t]{2}{*}{ Leverage } & -0.319 & 0.004 & 0.027 \\
\hline & {$[-7.55]^{* * *}$} & {$[3.29]^{* * *}$} & {$[6.86]^{* * *}$} \\
\hline \multirow[t]{2}{*}{$R D$} & 1.510 & 0.014 & -0.262 \\
\hline & {$[10.34] * * *$} & {$[4.50]^{* * *}$} & {$[-15.28]^{* * *}$} \\
\hline \multirow[t]{2}{*}{$C A R$} & -0.130 & & 0.017 \\
\hline & {$[-7.55]^{* * *}$} & & {$[13.85]^{* * *}$} \\
\hline \multirow[t]{2}{*}{ ReturnVolatility } & -0.434 & 0.072 & -0.727 \\
\hline & {$[-3.94] * * *$} & {$[4.08]^{* * *}$} & {$[-14.12]^{* * *}$} \\
\hline \multirow[t]{2}{*}{ Num_Analysts } & 0.010 & 0.000 & 0.001 \\
\hline & {$[6.97] * * *$} & {$[-5.10]^{* * *}$} & {$[6.65]^{* * *}$} \\
\hline \multirow[t]{2}{*}{ Instown_Perc } & 0.040 & 0.010 & 0.026 \\
\hline & {$[1.65]^{*}$} & {$[10.81]^{* * *}$} & {$[11.91] * * *$} \\
\hline \multirow[t]{2}{*}{ Tobins $Q$} & 0.651 & & \\
\hline & {$[43.08] * * *$} & & \\
\hline \multirow[t]{2}{*}{ SizeAdjRet } & & -0.075 & \\
\hline & & {$[-14.68] * * *$} & \\
\hline \multirow[t]{2}{*}{$R O A$} & & & 0.646 \\
\hline & & & {$[69.05]^{* * *}$} \\
\hline \multirow[t]{2}{*}{ Intercept } & 0.148 & -0.033 & 0.007 \\
\hline & {$[11.85]^{* * *}$} & {$[-27.22] * * *$} & {$[1.80]^{*}$} \\
\hline Year fixed effects & Yes & Yes & Yes \\
\hline Industry fixed effects & Yes & Yes & Yes \\
\hline Firm clustering & Yes & Yes & Yes \\
\hline $\mathrm{N}$ & 56,170 & 62,854 & 63,037 \\
\hline Adj. $R^{2}$ & $61.4 \%$ & $35.6 \%$ & $61.1 \%$ \\
\hline
\end{tabular}




\section{Table 7. Regression Results of Firm Value (Cont.)}

Panel B: Regression results using firm-years around CEO turnovers

\begin{tabular}{|c|c|c|c|}
\hline & $\begin{array}{c}\text { Tobins } Q \\
\text { (1) }\end{array}$ & $\begin{array}{c}\text { SizeAdjRet } \\
\text { (2) }\end{array}$ & $\begin{array}{c}R O A \\
(3)\end{array}$ \\
\hline \multirow[t]{2}{*}{ CharityImprove } & -0.204 & -0.000 & 0.009 \\
\hline & {$[-2.39] * *$} & {$[-0.05]$} & {$[0.82]$} \\
\hline \multirow[t]{2}{*}{ Post } & 0.032 & 0.008 & 0.023 \\
\hline & {$[1.05]$} & {$[9.22]^{* * *}$} & {$[8.29]^{* * *}$} \\
\hline \multirow[t]{2}{*}{ CharityImprove $\times$ Post } & 0.237 & -0.000 & -0.009 \\
\hline & {$[2.74] * * *$} & {$[-0.01]$} & {$[-0.83]$} \\
\hline \multirow[t]{2}{*}{$\log _{-} A T$} & -0.045 & 0.001 & -0.002 \\
\hline & {$[-7.87]^{* * *}$} & {$[4.60]^{* * *}$} & {$[-3.64] * * *$} \\
\hline \multirow[t]{2}{*}{$M T B$} & 0.002 & 0.000 & 0.001 \\
\hline & {$[0.62]$} & {$[0.07]$} & {$[2.76]^{* * *}$} \\
\hline \multirow[t]{2}{*}{ Leverage } & -0.323 & 0.003 & 0.026 \\
\hline & {$[-7.14] * * *$} & {$[2.28] * *$} & {$[6.32]^{* * *}$} \\
\hline \multirow[t]{2}{*}{$R D$} & 1.475 & 0.013 & -0.257 \\
\hline & {$[9.65]^{* * *}$} & {$[4.02]^{* * *}$} & {$[-14.15]^{* * *}$} \\
\hline \multirow[t]{2}{*}{$C A R$} & -0.134 & & 0.017 \\
\hline & {$[-7.31] * * *$} & & {$[12.94]^{* * *}$} \\
\hline \multirow[t]{2}{*}{ ReturnVolatility } & -0.463 & 0.069 & -0.706 \\
\hline & {$[-4.00] * * *$} & {$[3.68]^{* * *}$} & {$[-12.95]^{* * *}$} \\
\hline \multirow[t]{2}{*}{ Num_Analysts } & 0.01 & -0.000 & 0.001 \\
\hline & {$[6.61]^{* * *}$} & {$[-4.48] * * *$} & {$[6.17]^{* * *}$} \\
\hline \multirow[t]{2}{*}{ Instown_Perc } & 0.041 & 0.009 & 0.025 \\
\hline & {$[1.56]$} & {$[9.45]^{* * *}$} & {$[10.64]^{* * *}$} \\
\hline \multirow[t]{2}{*}{ Tobins $Q$} & 0.651 & & \\
\hline & {$[41.62] * * *$} & & \\
\hline \multirow[t]{2}{*}{ SizeAdjRet } & & -0.076 & \\
\hline & & {$[-13.97]^{* * *}$} & \\
\hline \multirow[t]{2}{*}{$R O A$} & & & 0.648 \\
\hline & & & {$[64.36]^{* * *}$} \\
\hline \multirow[t]{2}{*}{ Intercept } & 0.861 & -0.039 & -0.015 \\
\hline & {$[16.01]^{* * *}$} & {$[-25.43]^{* * *}$} & {$[-3.17] * * *$} \\
\hline Year fixed effects & Yes & Yes & Yes \\
\hline Industry fixed effects & Yes & Yes & Yes \\
\hline Firm clustering & Yes & Yes & Yes \\
\hline $\mathrm{N}$ & 41,034 & 44,866 & 45,040 \\
\hline $\operatorname{Adj} . R^{2}$ & $61.6 \%$ & $36.2 \%$ & $61.9 \%$ \\
\hline
\end{tabular}




\section{Table 8. Path Analysis of CEO Charity Involvement and Firm Value}

This table presents path analysis estimates for the relation between CEO charity involvement and firm value using three paths: employee welfare, customer satisfaction, and overall CSR performance. The definitions of all variables are reported in Appendix. Standard errors are clustered at the firm level, and $t$-statistics are reported as indicated. Year and industry fixed effects are both included. Significance at the $10 \%, 5 \%$, and $1 \%$ level are denoted *, $* *$, and $* * *$, respectively.

\begin{tabular}{|c|c|c|c|c|c|c|}
\hline & \multicolumn{2}{|c|}{ Path = Employee_KLD } & \multicolumn{2}{|c|}{ Path =Cus_Satis } & \multicolumn{2}{|c|}{ Path $=$ Total_KLD } \\
\hline & Coefficient & $t$-stat & Coefficient & $t$-stat & Coefficient & $t$-stat \\
\hline \multicolumn{7}{|l|}{$\underline{\text { Direct Path }}$} \\
\hline $\mathrm{P}($ Charity, Tobins $Q)$ & 0.0330 & $2.76^{* * *} *$ & 0.0252 & $1.76^{*}$ & 0.0330 & $2.76 * * *$ \\
\hline \multicolumn{7}{|l|}{ Mediated Path } \\
\hline $\mathrm{P}($ Charity, Path $)$ & 0.0384 & $2.75^{* * * *}$ & 0.8249 & $1.66^{*}$ & 0.2344 & $8.13 * * *$ \\
\hline $\mathrm{P}($ Path, Tobins $Q)$ & 0.0250 & $4.86 * * *$ & 0.0107 & 1.53 & 0.0162 & $6.69 * * *$ \\
\hline $\mathrm{P}($ Charity, $\mathrm{Path}) \times \mathrm{P}(\mathrm{Path}$, Tobins $Q)$ & 0.0010 & $2.40 * * *$ & 0.0088 & 1.12 & 0.0038 & $5.17 * * *$ \\
\hline Controls & \multicolumn{2}{|c|}{ Yes } & \multicolumn{2}{|c|}{ Yes } & \multicolumn{2}{|c|}{ Yes } \\
\hline Year fixed effects & \multicolumn{2}{|c|}{ Yes } & \multicolumn{2}{|c|}{ Yes } & \multicolumn{2}{|c|}{ Yes } \\
\hline Industry fixed effects & \multicolumn{2}{|c|}{ Yes } & \multicolumn{2}{|c|}{ Yes } & \multicolumn{2}{|c|}{ Yes } \\
\hline Firm clustering & \multicolumn{2}{|c|}{ Yes } & \multicolumn{2}{|c|}{ Yes } & \multicolumn{2}{|c|}{ Yes } \\
\hline $\mathrm{N}$ & \multicolumn{2}{|c|}{20,597} & \multicolumn{2}{|c|}{1,224} & \multicolumn{2}{|c|}{20,597} \\
\hline
\end{tabular}




\section{Table 9. Regression Results of Time Taken to be Promoted to Top Executives}

This table presents results from OLS regressions of the time taken for an individual to be promoted to a top executive on her charity involvement. The sample consists of 119,753 individuals who became top executives and 11,466 individuals who became top executives of public firms from 1950 to 2019. The definitions of all variables are reported in the Appendix. $t$-statistics are reported in brackets. Industry and career start year fixed effects are included. Significance at the $10 \%, 5 \%$, and $1 \%$ level are denoted $* * *$, and $* * *$, respectively.

\begin{tabular}{|c|c|c|}
\hline & TimeToTMT (Any firm) & TimeToTMT (Public firm) \\
\hline & $(1)$ & $(2)$ \\
\hline \multirow[t]{2}{*}{ Charity } & -1.544 & -0.866 \\
\hline & {$[-27.29]^{* * *}$} & {$[-7.14] * * *$} \\
\hline \multirow[t]{2}{*}{ NonCharity } & -1.824 & -1.018 \\
\hline & {$[-35.44]^{* * *}$} & {$[-10.79]^{* * *}$} \\
\hline \multirow[t]{2}{*}{ Woman } & 2.192 & 0.780 \\
\hline & {$[29.40]^{* * *}$} & {$[6.06]^{* * *}$} \\
\hline \multirow[t]{2}{*}{$M B A$} & -1.108 & -0.436 \\
\hline & {$[-20.84]^{* * *}$} & {$[-4.52] * * *$} \\
\hline \multirow[t]{2}{*}{ Grad_Law } & -0.107 & 0.300 \\
\hline & {$[-1.00]$} & [1.18] \\
\hline \multirow[t]{2}{*}{$C P A$} & -1.508 & -1.094 \\
\hline & {$[-20.88]^{* * *}$} & {$[-10.76]^{* * *}$} \\
\hline \multirow[t]{2}{*}{ Auditor } & -0.689 & -0.252 \\
\hline & {$[-5.79]^{* * *}$} & {$[-1.68]^{*}$} \\
\hline \multirow[t]{2}{*}{ Consultant } & -1.453 & -0.619 \\
\hline & {$[-20.61]^{* * *}$} & {$[-4.50] * * *$} \\
\hline \multirow[t]{2}{*}{ Banking } & 0.175 & -0.645 \\
\hline & {$[2.36] * *$} & {$[-2.78] * * *$} \\
\hline \multirow[t]{2}{*}{ Legal } & 0.863 & -0.192 \\
\hline & {$[5.43] * * *$} & {$[-0.52]$} \\
\hline \multirow[t]{2}{*}{ Investment } & -2.570 & -1.246 \\
\hline & {$[-37.49]^{* * *}$} & {$[-8.02]^{* * *}$} \\
\hline \multirow[t]{2}{*}{ PriorJobs } & 1.755 & 1.250 \\
\hline & {$[72.15]^{* * *}$} & {$[19.55]^{* * *}$} \\
\hline \multirow[t]{2}{*}{ Log_Network } & 0.534 & 0.119 \\
\hline & {$[37.01]^{* * *}$} & {$[3.58]^{* * *}$} \\
\hline \multirow[t]{2}{*}{$\log _{-} A T$} & & 0.443 \\
\hline & & {$[20.91] * * *$} \\
\hline \multirow[t]{2}{*}{$M T B$} & & 0.000 \\
\hline & & {$[0.80]$} \\
\hline \multirow[t]{2}{*}{ Leverage } & & 0.000 \\
\hline & & {$[-0.93]$} \\
\hline \multirow[t]{2}{*}{ Intercept } & 19.429 & 20.145 \\
\hline & {$[246.57]^{* * *}$} & {$[96.74]^{* * *}$} \\
\hline Industry fixed effects & Yes & Yes \\
\hline Start-year fixed effects & Yes & Yes \\
\hline $\mathrm{N}$ & 119,753 & 11,466 \\
\hline Adj. $R^{2}$ & $31.5 \%$ & $63.3 \%$ \\
\hline
\end{tabular}

